\title{
Abordagem vacinal bivalente baseada na fusão genética de seqüiência derivada da proteína circunsporozoíta (CS) \\ de Plasmodium yoelii com a flagelina FliCd de Salmonella enterica
}

Dissertação apresentada
ao Departamento de
Microbiologia do Instituto
de Ciências Biomédicas da
Universidade de São
Paulo, para obtenção do
Título de Mestre em
Ciências (Microbiologia).




\section{Abordagem vacinal bivalente baseada na fusão genética de seqüência derivada da proteína circunsporozoíta (CS) de Plasmodium yoelii com a flagelina FliCd de Salmonella enterica}

Dissertação apresentada
ao Departamento de
Microbiologia do Instituto
de Ciências Biomédicas da
Universidade de São
Paulo, para obtenção do
Título de Mestre em
Ciências (Microbiologia).

ORIENTADOR: Prof. Dr. LUÍS CARLOS DE SOUZA FERREIRA 


\section{UNIVERSIDADE DE SÃO PAULO INSTITUTO DE CIÊNCIAS BIOMÉDICAS}

Candidato(a): Catarina Joelma Magalhães Braga

Título da Dissertação: Abordagem vacinal bivalente baseada na fusão genética de sequiência derivada da proteína circunsporozoíta (CS) de Plasmodium yoelii com a flagelina FliCd de Salmonella entérica

Orientador: Luís Carlos de Souza Ferreira

A comissão Julgadora dos trabalhos de Defesa da Dissertação de Mestrado, em sessão pública realizada a considerou o(a)
( ) Aprovado(a)
( ) Reprovado(a)

1) Examinador(a) Assinatura:

Nome:

Instituição:

2) Examinador(a) Assinatura:

Nome:

Instituição:

3) Presidente: Assinatura:

Nome:

Instituição: 


\section{DEDICATÓRIA}

Ao Jacob

Pela amizade, carinho e incondicional apoio 


\section{AGRADECIMENTOS}

Os dados apresentados nessa dissertação de mestrado foram construídos ao longo do curso com auxílio de vários colaboradores

Ao Prof. Dr. Luís Carlos de Souza Ferreira, pelo apóio e orientação no início de minha vida acadêmica e pelo seu exemplo de pesquisador incansável e orientador presente e exigente na medida necessária para o nosso crescimento.

À dra. Maria Elisabete Sbrogio, pelo apoio incondicional e carinho com que nos ensina as mais diversas atividades. Sem seu apoio a realização deste trabalho não seria possível.

À Rita de Cássia Café Ferreira, por ter me aceito para trabalhar neste grupo, se não fosse você eu não teria vindo e ficado até este momento.

Ao Prof. Dr. Maurício Rodrigues e sua aluna Bruna Alencar pelas sugestões e ajuda nas metodologias ligadas a respsota celular.

À Liliana Moura Massis por sua colaboração em todas as atividades realizadas no trabalho e pela amizade e companhia em momentos felizes e difícies do grupo flagelina.

Aos meus colegas do laboratório CEVAT-GENE 3 E 4: Juliano, Wilson, Bruna, Otto, Marcelo, Priscila, Milene, Elisa, Bruno, Luana, Karine, Lívia, Fabiano, Cristiane, Camila Santos, Domingos, Renata, Aline, Hugo, Camila Lauand pelos momentos de descontração e dicas para a realização deste trabalho.

Ao Rafael, por trazer calor a minhavida e pela amizade sincera

À Mariana pela amizade e pela ajuda na execução de muitos ensaios celulares

Aos colegas do laboratório do Prof. Dr. Carlos Menck e do Prof. Dr. 
Carlos Taborda pelas parcerias e dicas para a realização deste trabalho

À Camila Calderon, Maria Normandia e Kasui Higuchi pelo excelente apóio técnico.

Ao Carlos Augusto dos Santos por sua dedicação ao biotério e aos animais de experimentação

À Juliana Falcão pela amizade-irmã e pelas intensas discussões em microbiologia, imunologia, genética, música, arte, enfim, sobre todas as coisas da vida. Conviver com você é "crescer" todos os dias.

À Sandriana pela agradável convivência e por suportar minhas "neuras" e questionamentos em imunologia. Sua contribuição foi indispensável para o crescimento filosófico deste trabalho.

Aos meus familiares pelo carinho e pela torcida e por suportar minha ausência.

Aos amigos Susy, Moacir, Claudinha, Isabelle e Sérgio pela torcida e apóio para a realização deste sonho.

Ao Ricardo pela paciência e pelos momentos de descontração. 
Este trabalho foi realizado sob orientação do Prof. Dr. Luís Carlos de Souza Ferreira, no Centro de Vacinas e Terapias Gênicas (CEVAT-GENE 4), no Departamento de Microbiologia do Instituto de Ciências Biomédicas da Universidade de São Paulo, com apoio financeiro da CAPES. 


\section{LISTA DE ABREVIATURAS E SIGLAS}

APC- células apresentadoras de antígenos

CD- células dendríticas

CFA- adjuvante comple de Freund

CFA/I- fator de colnização I de E. coli

CFSE ou CFDA SE- carboxyfluorescein fluorescein diacetate, succinimidyl Ester

COX-2- ciclooxigenase 2

CpG- DNA rico em seqüências de citosina e guanosina

CS- circunsporozoíta

CTL- linfócitos $\mathrm{T} \mathrm{CD} 8^{+}$citotóxicos

CTP-3- sub-unidade B da toxina colérica

DNA- ácido desoxiribonucléico

ELISPOT- Enzyme-linked immunosorbent spot

FAS- membro 6 da família de TNF de citocinas e moléculas de superfície

FliC $d$ - flagelina tipo $\mathrm{d}$

FliC $i$ - flagelina tipo i

FljB- flagelina tipo B

GM-CSF- fator estimulante de colônia de macrófago e granulócito

ICAM- intercellular adhesion molecule

iNOS- óxido nítrico sintetase induzível

IFA- adjuvante incompleto de Freund

IFN- $\gamma$ - interferon gama

IgG - imunoglobulina $\mathrm{G}$

IL-1- interleucina 1

IL-2- interelucina 2

IL-6- interleucina 6

IL-10- interleucina 10

IL-12p70- interleucina doze cadeia 70

LB- Luria-Bertani

LPS- lipopolissacarídeo 
LT $\propto-$ leucotrieno alfa

LTß- leucotrieno beta

LLO- exotoxina listeriolisina O produzida por Listeria monocytogenes,

MHC- complexo principal de histocompatibilidade

MyD88- fator de diferenciação mielóide

NF-אB- translocação do fator nuclear de transcrição

NO- óxido nítrico

OVA- ovalbumina

PA - Persulfato de amônia

PBS- tampão salina fostato

PBS-T- tampão salina fosfato mais $0,5 \%$ de tween 20

PVF- proteína verde fluorescente

pCS- peptídeo CS

q.s.q - quantidade suficiente para

SDS - duodecil sulfato de sódio

SDS-PAGE - eletroforese em gel de poliacrilamida na presença de duodecil sulfato de sódio

SIDA- síndrome da imunodeficiência adquirida

TLR- Toll-like receptor

$\mathrm{TNF}-\propto$ - fator de necrose tumoral alfa

VCAM- molécula de adesão de célula vascular

VLP- partículas semelhantes a vírus 


\section{LISTA DE SÍMBOLOS}

Aminoácidos

Aminoácido

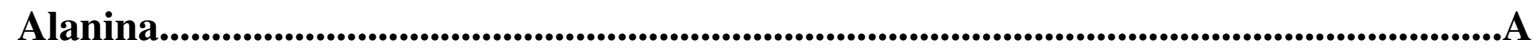

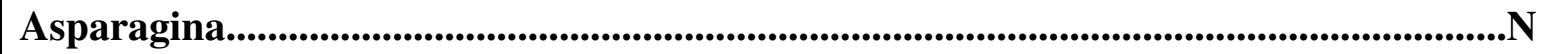

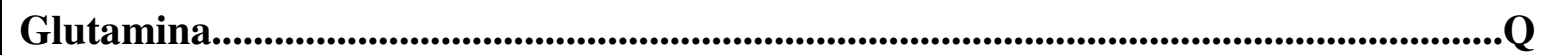

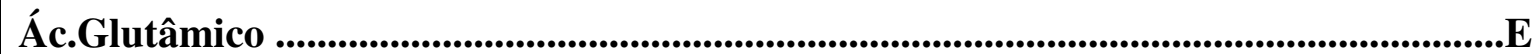

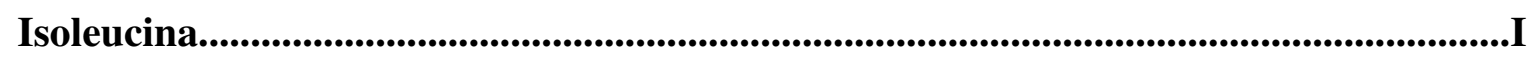

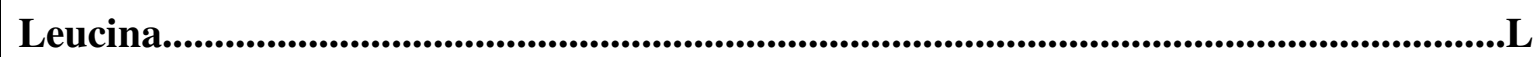

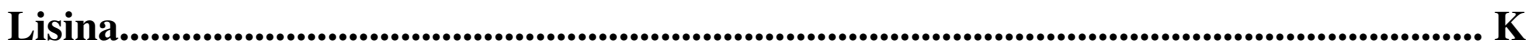

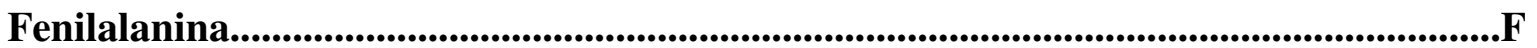

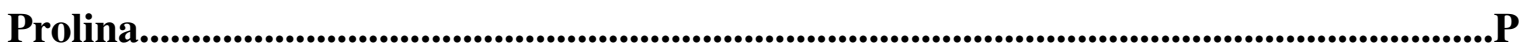

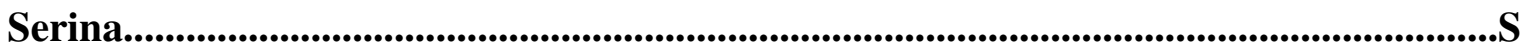

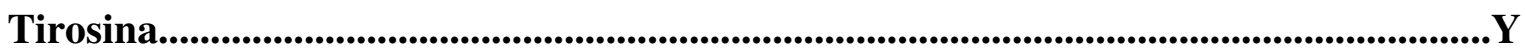

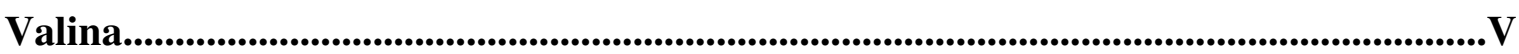




\section{RESUMO}

BRAGA, C.J.M. Abordagem vacinal bivalente baseada na fusão genética de seqüência derivada da proteína circunsporozoíta (CS) de Plasmodium yoelii com a flagelina FliCd de Salmonella entérica. 2007. 76 f. Dissertação (Mestrado em Microbiologia)- Instituto de ciências Biomédicas, Universidade de São Paulo, São Paulo, 2007.

A busca de adjuvantes que estimulem de forma eficiente à resposta imune celular representa uma importante contribuição para a pesquisa de vacinas. $\mathrm{O}$ presente projeto tem como principal objetivo avaliar o efeito imunoestimulador de flagelinas expressas por linhagens de Salmonella sp., particularmente na ativação de respostas mediadas por células T CD8 ${ }^{+}$. Em uma primeira etapa, o potencial adjuvante das flagelinas $\mathrm{FliC} d$, FliC $i$ e FljB foi avaliado para ativação de células $\mathrm{T} \mathrm{CD} 8^{+}$específicas ao antígeno modelo OVA. Em uma segunda etapa pesquisamos com maior detalhamento os efeitos adjuvantes da flagelina com efeitos mais promissores $(\mathrm{FliC} d)$ frente a um epítopo $\mathrm{T} \mathrm{CD}^{+}$específico da proteína $\mathrm{CS}$ de P. yoelli. Para esse fim, animais foram submetidos a regimes de imunização baseados em vacinas de subunidades (flagelina co-administrada ou geneticamente fusionada ao antígeno alvo) ou linhagens atenuadas de $S$. Dublin que expressam flagelinas híbridas geneticamente fusionadas ao epitopo CS. Em todos os ensaios, a ativação de células $\mathrm{T}_{\mathrm{CD}}{ }^{+}$foi monitorada por ELISPOT em meio a estimulação com peptídeos específicos. Os resultados obtidos demonstram que a flagelina é capaz de modular o sistema imune, atuando particularmente na ativação de respostas mediadas por células $\mathrm{T} \mathrm{CD}^{+}$, sugerindo seu potencial para a composição de vacinas terapêuticas.

Palavras-chave: vacinas terapêuticas, células $\mathrm{T} \mathrm{CD}^{+}$, adjuvantes, flagelina, malária, proteína circumsporozoíta 


\begin{abstract}
Braga, C.J.M. Bivalent vaccines approches based in genetic fusion of sequence derived of the circumsporozoíta (CS) protein de Plasmodium yoelii with FliCd flagellin of Salmonella enterica. 2007. 76 f. Master thesis (Microbiology)- Instituto de ciências Biomédicas, Universidade de São Paulo, São Paulo, 2007.

The search for adjuvants that are able to stimulate an efficient cellular immune response represents an important contribution in vaccine development. In the present work, we evaluated immunostimulatory effect of flagellins expressed by Salmonella sp. strains, particularly on activation of $\mathrm{CD}^{+} \mathrm{T}$ cells. As a first step we used ovalbumin as a model antigen, co-administrated with FliC $d$, FliC $i$ and FliB flagellins, by parenteral path to evaluate the adjuvant potential of flagellins on the stimulation of $\mathrm{CD} 8^{+} \mathrm{T}$ specific responses. The second step involved the exploration of the adjuvant effect of the most promising of the flagellins (FliCd) using an epitope from the CS protein of $P$. yoelli. Mice were submitted to immunization with subunits vaccines (flagellin co-administrated or genetically fusioned to the target) to properly evaluate the adjuvant effect of the flagellin. Finally, we explored the vaccine potential of attenuated $S$. Dublin strains that expressed hybrid flagellin genetically fusioned to $\mathrm{CS}$ epitope. The $\mathrm{CD}^{+} \mathrm{T}$ cells activation was monitored by ELISPOT with specific peptides in all experiments. Our results show that flagellin is able to modulate the immune system, increasing $\mathrm{CD}^{+} \mathrm{T}$ cells activation, suggesting its potencial use in therapeutic vaccine approaches.
\end{abstract}

Key Words: therapeutic vaccine, $\mathrm{CD}^{+} \mathrm{T}$ cells, adjuvants, flagellin, malaria, circumsporozoite protein. 


\section{LISTA DAS TABELAS}

Tabela 01- Linhagens de Salmonella sp. utilizadas

Tabela 02- Seqüência dos oligonucleotídeos sintéticos representando o epitopo $\mathrm{T} C D 8^{+}$da proteína CS. 37

Tabela 03- Mobilidade das diferentes linhagens em meio semi-sólido .50 


\section{LISTA DE ILUSTRAÇÕES}

Figura 01- Representação esquemática da proteína CS de $P$. yoelii e localização do epitopo T $\mathrm{CD} 8^{+}$

Figura 02- Representação esquemática do vetor pLS408. .36

Figura 03- Resposta imune celular OVA-específica analisada por ELISPOT .46

Figura 04- Ativação de respostas OVA-específicas mediadas por células $\mathrm{T}$ CD8 ${ }^{+}$produtoras de IFN- $\gamma$.

Figura 05- Avaliação da citotoxicidade in vivo .48

Figura 06- Representação esquemática da localização do epitopo CS no gene da flagelina FliC $d$

Figura 07- Expressão in vitro das flagelinas híbridas por linhagens vacinais de $S$. Dublin.

Figura 08- Efeito adjuvante da flagelina FliCd para o peptídeo pCS de P. yoelli .52

Figura 09- Efeito adjuvante da flagelina FliCd para o peptídeo pCS de P. yoelli 53

Figura 10- Avaliação da citotoxicidade in vivo .54

Figura 11- Indução de resposta celular específica para o peptídeo pCS de $P$. yoelli .55 


\section{SUMÁRIO}

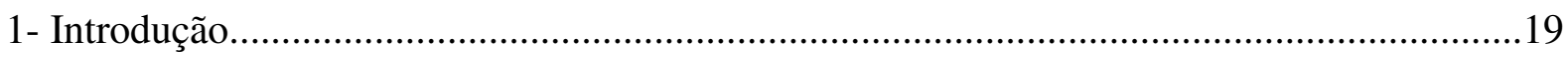

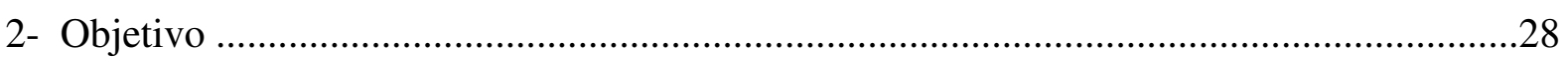

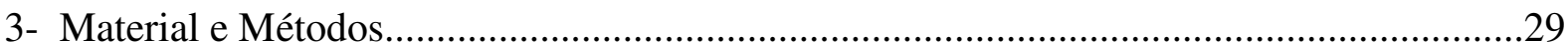

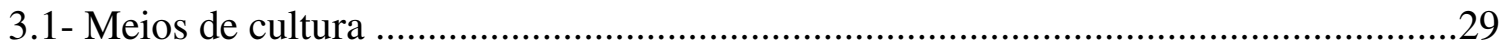

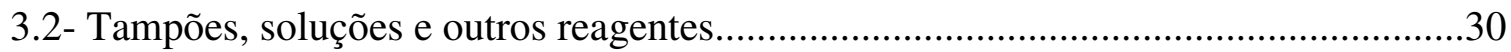

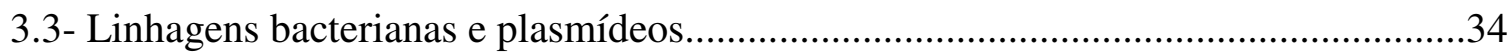

3.4- Olinucleotídeos sintéticos, anticorpos e outros reagente biológicos...........................36

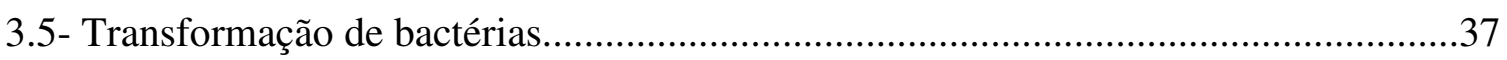

3.6- Inserção do epitopo $\mathrm{T} \mathrm{CD} 8^{+}$-SYVPSAEQI- na região hipervariável do gene flicd..38

3.7- Caracterização da expressão de flagelina pelas linhagens construídas........................39

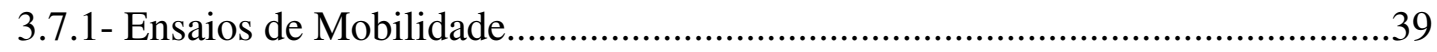

3.7.2- Preparação de flagelinas purificadas..................................................................39

3.7.3- Preparação de lisados celulares para gel de poliacrilamida.............................39

3.7.4- Imunodetecção em filtro de nitrocelulose (Western blot)...............................40

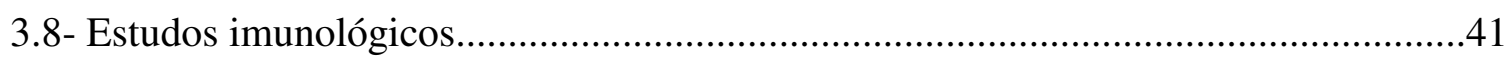

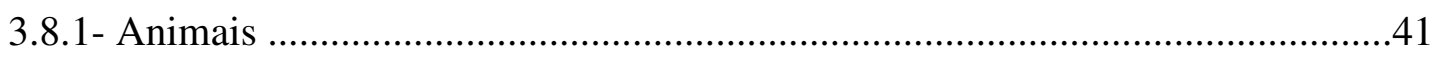

3.8.2- Protocolos de imunização ......................................................................... 41

3.8.2.1- Antígenos, peptídeos e adjuvantes nas imunizações ..........................41

3.8.2.2- Preparação das linhagens bacterianas para imunizações .....................41

3.8.3 - Ensaios celulares.......................................................42

3.8.3.1- ELISPOT (Enzyme-linked immunosorbent spot)................42

3.8.3.2- Citotoxicidade in vivo ...................................................................4

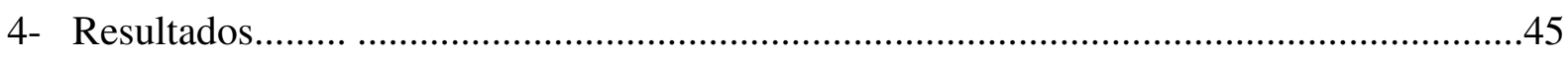

4.1. Efeito adjuvante das flagelinas FliCd, FliCi e FljB de Salmonella sp. na ativação de resposta imune celular específica para ovalbumina

4.2. Clonagem do epitopo $\mathrm{CS}_{280-288}$ na região hipervariável do gene que codifica para a flagelina FliCd de Salmonella sv. Dublin .48

4.3. Caracterização das linhagens vacinais de Salmonella quanto à expressão de flagelinas híbridas transportando epitopo CS de $P$. yoelli.

4.4. Avaliação do potencial adjuvante da flagelina FliCd de $S$. Dublin na ativação de resposta imune celular específica para o epitopo CS por diferentes vias. 
4.5. Salmonella atenuada como veículo vacinal para antígeno da malária .54

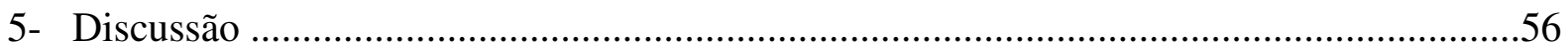

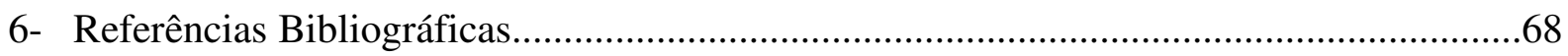




\section{1- Introdução}

A vacinação representa a estratégia de melhor custo-benefício para o controle de doenças infecciosas. A morbidade e a mortalidade devido a várias doenças infecciosas têm sido dramaticamente reduzidas pelo uso generalizado de vacinas. Dentre os vários exemplos de sucesso destaca-se a erradicação da varíola há mais de duas décadas e o desaparecimento de casos de poliomielite nas Américas, Europa, Austrália e outros continentes, indicando que a poliomielite será o próximo alvo para erradicação mundial (GIUDICE, 2003). As vacinas disponíveis até o momento são de aplicação profilática, mas existe a necessidade de pesquisas direcionadas para elaboração de abordagens terapêuticas, importantes na contenção de doenças infecciosas crônicas tais como a síndrome da imunodeficiência adquirida (SIDA), hepatite $\mathrm{C}$ e malária. De um modo geral, complicações dessas doenças surgem como resultado de resposta imune celular insuficiente ou inadequada para a eliminação de patógenos intracelulares ou pela indução de tolerância imunológica.

As vacinas terapêuticas têm o objetivo de prevenir complicações severas de uma infecção ou doença crônica, uma vez que reforçam ou ampliam as defesas imunológicas quando o indivíduo é incapaz de responder durante o curso natural da doença ou quando a terapia antimicrobiana não é suficiente. A principal característica deste tipo de abordagem é a ativação de linfócitos $\mathrm{T} \mathrm{CD}^{+}$citotóxicos (CTL) responsáveis pela destruição de células infectadas. Enquanto anticorpos exercem papel chave na neutralização do patógeno, linfócitos $\mathrm{T} \mathrm{CD}^{+}$citotóxicos podem destruir células infectadas e impedir a progressão da doença (AUTRAN et al., 2004). Abordagens terapêuticas representam uma valiosa estratégia quando as seguintes condições são encontradas: (i) nenhum tratamento específico é disponível ou eficaz contra o patógeno ou a doença; (ii) agentes antimicrobianos não podem erradicar o patógeno, selecionando cepas resistentes; (iii) o agente antimicrobiano é muito tóxico para ser administrado por longos períodos; (iv) o status de carregador crônico, com baixa carga do patógeno, precede um conjunto de sintomas que reflete na proliferação do patógeno, inflamação crônica ou transformação maligna de lesões induzidas pelo patógeno; (v) algum grau de resposta imune é demonstrado durante o curso natural da infecção (AUTRAN et al., 2004).

A malária é uma doença crônica severa distribuída mundialmente. Em humanos, é causada por um dos quatro parasitas: Plasmodium falciparum, $P$. vivax, $P$. malariae e $P$. 
ovale, sendo que o último não é encontrado no Brasil. Cerca de $40 \%$ da população mundial (2,4 bilhões de pessoas) está exposta à malária, especialmente pessoas que vivem em países tropicais e sub-tropicais. Nessas regiões, aproximadamente 300 a 500 milhões de novos casos são diagnosticados a cada ano, causando 1,5 a 2,7 milhões de mortes por ano, principalmente entre crianças na África (WHO, 2002). No Brasil, desde a década de 70, quando apenas 52.000 casos foram registrados, a incidência da doença vem aumentando gradualmente. Em 1990, o número de casos superou 500.000 e em 1999, mais de 610.000 casos foram notificados, sendo 99\% oriundos da região Amazônica (MINISTÉRIO DA SAÚDE, 2003; JONES e HOFFMAN, 1994).

A ineficácia das estratégias de controle e tratamento da malária tem contribuído para o aumento da incidência da doença no mundo, e reforçam a necessidade de desenvolvimento de uma vacina. Porém vários fatores têm impedido o desenvolvimento de uma vacina segura para a malária, dentre eles está a complexidade do ciclo de vida do parasito, a ampla variedade de respostas imunológicas induzidas e a falta de conhecimento dos mecanismos imunológicos que medeiam a proteção (WATERS et al., 2005). No entanto, existem várias razões para investir no desenvolvimento de uma vacina para a malária. Em pessoas que adquiriram algum grau de imunidade devido a exposição crônica à malária, parasitemia pode existir sem os sintomas da doença, sendo que essas pessoas são também menos propensas a morrer de complicações devido à malária (JONES et al., 1994).

Estudos pioneiros realizados pelo grupo do Dr. Nussenzweig, demonstraram que imunidade protetora contra a malária pode ser induzida em animais e humanos por imunização com esporozoítas atenuados por radiação gama (NUSSENZWEIG et al., 1986). Os mecanismos imunológicos envolvidos na resposta protetora incluem a produção de anticorpos específicos para antígenos da superfície de esporozoítas, ativação de células $\mathrm{T}$ $\mathrm{CD}^{+}$e células T CD8 ${ }^{+}$(NUSSENZWEIG et al., 1989; JONES et al., 1994). Desse modo, formas sanguíneas podem ser eliminadas pela ligação a anticorpos opsonizantes dirigidos para estruturas da superfície do patógeno. Por outro lado, as formas intracelulares do parasita, podem ser eliminadas por respostas citotóxicas mediadas por células $\mathrm{T} \mathrm{CD} 8^{+}$. Estas células são capazes de reconhecer epítopos derivados do parasita em associação a moléculas do complexo principal de histocompatibilidade classe I (MHC-I) e promover a destruição das células infectadas, impedindo a continuidade do ciclo celular do parasita (KAPPE et al., 2004).

Em 1977, estudos realizados com camundongos deficientes de células B mostraram 
que esses animais foram protegidos da infecção após imunização com esporozoítas atenuados por radiação, indicando que apenas linfócitos $\mathrm{T}$ foram suficientes para induzir imunidade protetora nesses animais (CHEN et al., 1977). Em 1987 e 1988, dois grupos independentes demonstraram que a imunidade induzida em camundongos por esporozoítas atenuados por radiação foi dependente de linfócitos $\mathrm{T} \mathrm{CD}^{+}$(SCHOFIEL et al., 1987 and WEISS et al., $1988^{1}$ apud RODRIGUES et al., 2003). Esta foi a primeira evidência de que esta subpopulação de linfócitos participou na imunidade contra parasitas intracelulares não virais. Posteriormente, o papel de linfócitos $\mathrm{T} \mathrm{CD}^{+}$citotóxicos (CTL) na imunidade à malária foi reforçado pela demonstração de que a transferência passiva de células T CD8 ${ }^{+} \mathrm{CS}$-específicas para camundongos virgens era capaz de mediar a proteção contra o desafio com P. berghei e P. yoelii, agentes da malária em murinos (TSUJI e ZAVALA, 2003; RODRIGUES et al., 1991). Pesquisas subseqüentes mostraram que células $\mathrm{T} \mathrm{CD}^{+}$citotóxicas são também importantes na imunidade a infecções causadas por outros parasitas intracelulares tais como Trypanosoma cruzi e Toxoplasma gondii (RODRIGUES et al., 2003). Pelas suas características imunológicas, a imunidade mediada por células $\mathrm{T}$ citotóxicas representa prioridade para o desenvolvimento de uma vacina com propriedades profiláticas e terapêuticas contra a malária.

Pesquisas de alvos antigênicos para vacinas contra a malária com potencial para ativação de linfócitos $\mathrm{T} \mathrm{CD}^{+}$citotóxicos voltaram-se para uma proteína de superfície com estrutura primária definida, a proteína circunsporozoíta (CS). Essa proteína é encontrada em grande quantidade na superfície de esporozoítos de todas as espécies de Plasmodium e possui papel central na invasão de hepatócitos (KAPPE et al., 2004). Em camundongos imunizados com esporozoítas atenuados por radiação, linfócitos $\mathrm{T} C D 8^{+}$foram específicos para um único epítopo encontrado na região C- terminal da proteína CS de P. yoelii e P. berghei (ROMERO et al., 1989, RODRIGUES et al., 1991). Este epítopo, representado na figura 1 pela seqüência de aminoácidos SYVPSAEQI, é reconhecido por linfócitos T $\mathrm{CD}^{+}$restritos para o $\mathrm{MHC} \mathrm{H}-2$ $\mathrm{K}^{\mathrm{d}}$ e seu papel na proteção à malária murina foi confirmado em diversos estudos, o que impulsionou o desenvolvimento de vacinas baseadas no antígeno CS (ROMERO et al., 1989; WEISS et al.,1990; RODRIGUES et al.,1991; ASEGUINOLAZA et al.,2003). Em voluntários imunizados com esporozoítas de $P$. falciparum atenuados por radiação, foi demonstrado a presença de linfócitos $\mathrm{T} \mathrm{CD}^{+}$reativos, indicando que a proteína CS é uma forte candidata para a elaboração de vacinas contra a malária em humanos (MALIK et al, 
1991).

\section{CS Protein of Plasmodium yoelii}

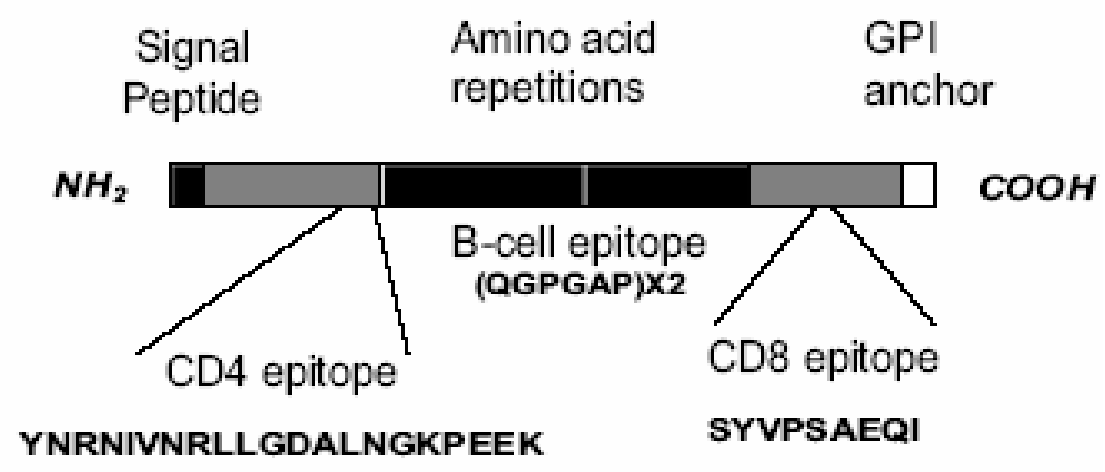

Figura 1: Representação esquemática da proteína CS de $P$. yoelii e localização do epitopo T CD8 ${ }^{+}$em estudo (RODRIGUES et al, 2003). As CSs de diferentes espécies de Plasmodium mostram uma estrutura comum que inclui um peptídeo sinal, uma região central composta principalmente de seqüências repetidas de aminoácidos que definem epítopos para células B e regiões N- e C-terminais conservadas. No esquema, também é mostrado o epitopo T CD4 ${ }^{+}$localizado na região $\mathrm{N}$-terminal e o epitopo $\mathrm{T} \mathrm{CD}^{+}$em estudo localizado na porção C-terminal, aminoácidos 280 a $288\left(\mathrm{CS}_{280-288}\right)$.

Diferentes veículos vacinais têm sido empregados na ativação de células T CD8 ${ }^{+}$ específicas para o epitopo da CS em camundongos. Tais abordagens incluem vetores vacinais vivos, como vírus e bactérias recombinantes, vacinas de DNA, partículas semelhantes a vírus (VLP) e peptídeos sintéticos. Os vetores virais utilizados para ativar células T CD8 ${ }^{+}$ específicas ao epitopo CS, de um modo geral, conferiram diferentes graus de imunidade protetora contra esporozoítas do P. yoelii (revisado SOARES e RODRIGUES, 1998). No entanto, a combinação de dois vetores virais expressando a proteína CS demonstrou ser superior a formulações vacinais baseadas apenas em um tipo de vírus (LI et al., 1993; ROMERO et al, 2001; ASEGUINOLAZA et al., 2003). Outros estudos baseados em vacinas de DNA contendo o gene inteiro da proteína CS seguido por uma dose de reforço com vetor viral codificando o epitopo CS relataram aumento significativo na indução de respostas mediadas por células T CD8 ${ }^{+}$-específicas (SEDEGAH et al., 1998; SEDEGAH et al., 2000).

Vacinas baseadas em linhagens atenuadas de Salmonella $s p$. foram utilizadas para expressar a proteína CS de Plasmodium (SADOFF et al., 1988; AGGARWAL et al., 1990). Os resultados demonstraram que animais imunizados por via oral com salmonelas 
recombinantes foram parcialmente protegidos do desafio com esporozoítas viáveis de $P$. berghei, na ausência de anticorpos CS-específicos, sugerindo que células $\mathrm{T}$ mediaram a proteção (SADOFF et al., 1988; AGGARWAL et al., 1990). Além disso, foi demonstrado que células T CD8 ${ }^{+}$citotóxicas específicas para CS foram responsáveis pela proteção parcial e que a depleção dessas células in vivo anulava o efeito (AGGARWAL et al., 1990). No entanto, apesar dos esforços realizados, não foi possível obter uma vacina efetiva e segura contra a malária. Contudo, os resultados obtidos até o momento demonstram a importância de pesquisas que resultem na descoberta de novas abordagens vacinais com maior poder estimulador de células $\mathrm{T} \mathrm{CD} 8^{+}$citotóxicas específicas.

De um modo geral, formulações vacinais baseadas em microrganismos vivos atenuados são potentes indutores de imunidade celular. Porém, preocupações com a segurança dessas vacinas têm encorajado o uso de antígenos cada vez mais purificados. No entanto, proteínas purificadas não são bons indutores de células $\mathrm{T} \mathrm{CD}^{+}$e, freqüentemente, torna-se necessário à incorporação de adjuvantes para estimular adequadamente o sistema imunológico (KRIEG, 2007). Nos últimos anos, a busca por adjuvantes que promovam eficiente estimulação de células $\mathrm{T} \mathrm{CD}^{+}$representa uma prioridade para o desenvolvimento de vacinas profiláticas e terapêuticas (CUADROS et al., 2004; O'HAGAN et al., 2001). Entre os adjuvantes com potencial para uso em vacinas terapêuticas destacam-se os produtos de origem microbiana tais como: toxinas, DNA rico em seqüências de citosina e guanosina (CpG DNA) não metiladas, componentes de parede celular bacteriana, lipopolissacarídeo (LPS) e flagelina.

A descoberta de que o adequado desenvolvimento da resposta imune adaptativa (mediada por linfócitos $\mathrm{B}$, linfócitos $\mathrm{T}_{\mathrm{CD}} 4^{+}$e $\mathrm{T} \mathrm{CD}^{+}$) é necessário a ativação inicial de componentes da imunidade inata, revolucionou o conhecimento sobre como as vacinas trabalham para estimular o sistema imunológico. Hoje é amplamente difundido que a eficácia de uma vacina é intimamente dependente do seu potencial para ativar componentes da imunidade inata. As células apresentadoras de antígenos (APC), como os macrófagos e células dendríticas, fazem parte da imunidade inata e exercem papel central no desenvolvimento da resposta imune adaptativa. Enquanto linfócitos $\mathrm{B}$ reconhecem diretamente o antígeno solúvel através de seus receptores de superfície, linfócitos T CD4 ${ }^{+}$e T $\mathrm{CD}^{+}$necessitam que o antígeno seja processado e apresentado, em associação a moléculas do complexo principal de histocompatibilidade (MHC), por uma APC. Neste sentido, as células dendríticas (CD) são as mais potentes das APC na capacidade de estimular células T 
virgens. (STEINMAN e POPE, 2002; CHUNG et al, 2004). Estudos recentes demonstraram que a ativação e a maturação de $\mathrm{CD}$ pode ser iniciada pela ligação de produtos solúveis a seus receptores de superfície. Desta forma, o emprego de adjuvantes que ativam CD representa uma prioridade para o aumento da eficácia das vacinas.

A flagelina, proteína estrutural do filamento flagelar bacteriano, é reconhecida por suas propriedades imunoestimuladoras, sendo considerada um adjuvante promissor para vacinas terapêuticas (MURTHY et al., 2004; CUNNINGHAM et al., 2004). Os mecanismos pelos quais a flagelina estimula o sistema imunológico são amplamente conhecidos e ocorre, principalmente, pela ativação do receptor Toll-like receptor 5 (TLR 5), encontrado na superfície de monócitos, macrófagos, $\mathrm{CD}$ e células epiteliais. Após a ligação da flagelina ao TLR 5, ocorre o recrutamento de proteínas adaptadoras, incluindo o fator de diferenciação

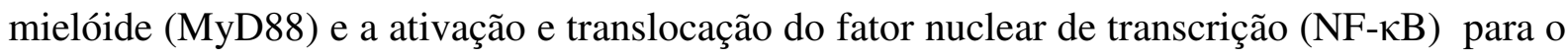
núcleo da célula, onde este inicia a expressão de diversos genes que desempenham papel crítico na resposta imune inata. Dentre os genes-alvo de NF-kB estão os genes de citocinas (IL-1, IL-2, IL-6, IL-10, IL-12p70, TNF- $\propto$, IFN- $\gamma$, LT $\propto$, LTß e GM-CSF), moléculas de adesão (ICAM, VCAM) e enzimas induzíveis (iNOS e COX-2) (HONKO e MIZEL, 2005; ZHANG e GHOSH, 2001; APPLEQUIST et al., 2005). Essas observações indicam que a flagelina pode induzir respostas celulares do tipo Th1, importante para o estabelecimento de respostas mediadas por linfócitos $\mathrm{T}$ citotóxicos. Em adição, a estimulação de TLR na superfície de CD promove sua ativação e maturação, o que inclui aumento da expressão do MHC e moléculas co-estimuladoras (B7-1 e B7-2), bem como secreção de citocinas e quimiocinas pró-inflamatórias, conseqüentemente, a maturação das $\mathrm{CD}$ aumenta a capacidade destas em sensibilizar células T (RANVIDRAN et al., 2005, KAISHO e AKIRA, 2002; HONKO e MIZEL, 2005; HONKO et al., 2006; CUADROS, et al, 2004; PINO et al, 2005; McSORLEY et al, 2000; McSORLEY et al, 2002; TAKEDA et al, 2003; AKIRA et al, 2004).

Dependendo da espécie bacteriana, a flagelina pode ter massa molecular que varia de 28 a $80 \mathrm{kDa}$. Cerca 20.000 ou mais cópias de flagelinas são polimerizadas para formar o filamento flagelar bacteriano. Este filamento está ligado a duas estruturas, o gancho e o corpo basal, formando o flagelo; que uma vez montado, é exposto na superfície bacteriana e funciona como um propulsor, conferindo mobilidade a bactéria e auxiliando na adesão às células do hospedeiro (NEWTON \& STOCKER, 1991; MURTHY et al., 2004; CUNNINGHAM et al., 2004). As várias espécies de Salmonella sp. produzem diferentes flagelinas (FliCd, FliCi, FljB), porém, o alinhamento das sequiências de aminoácidos dessas 
flagelinas demonstrou regiões terminais conservadas $(\sim 170 \mathrm{~N}$ - e 100C- resíduos terminais de aminoácidos), flanqueando uma região central hipervariável tanto na composição de resíduos como no tamanho (NEWTON et al., 1989; YONEKURA et al., 2003; RAMOS et al., 2004; WEI et al., 1985). As regiões $\mathrm{N}$ e C- terminais da flagelina formam uma estrutura em $\propto-$ hélice, e constituem os domínios $\mathrm{D}_{0}$ e $\mathrm{D}_{1}$, posicionados no centro do filamento flagelar. Essas regiões são necessárias para montagem do filamento flagelar, função de mobilidade e ainda, interação com o TLR 5 A região hipervariável da flagelina é exposta como uma folhar $\beta$ pregueada (domínios $\mathrm{D}_{2}$ e $\mathrm{D}_{3}$ ) na superfície externa do filamento flagelar e apresenta apenas $30 \%$ de homologia entre as espécies de Salmonella. Esta região é rica em epítopos B e é base da sorotipagem do antígeno H (YONEKURA et al., 2003; RAMOS et al., 2004; MURTHY et al., 2004; FLYNN et al., 1990).

Devido suas características imunoestimuladoras intrínsicas, diferentes tipos de flagelinas derivadas de Salmonella sp. foram utilizadas como adjuvante em formulações vacinais destinadas para ativação de respostas humorais e celulares. As primeiras abordagens utilizando flagelinas de Salmonella sp. iniciaram com o grupo da Dra. Newton em 1989. A estratégia proposta inicialmente, consistia na clonagem de oligonucleotídeos sintéticos, codificando epítopos para ativação de linfócitos $\mathrm{B}, \mathrm{T} \mathrm{CD}^{+}$ou $\mathrm{T} \mathrm{CD} 8^{+}$, na região central hipervariável dos genes responsáveis pela codificação de diferentes flagelinas, e sua expressão por linhagens atenuadas de Salmonellas sp. A primeira experiência utlizando o sistema de apresentação de antígeno em fusão com a flagelina de Salmonella buscou a expressão de um epítopo derivado da sub-unidade B da toxina colérica (o epítopo CTP-3). Após a imunização parenteral, os camundongos imunizados desenvolveram altos títulos de anticorpos antitoxina (NEWTON et al., 1989). Desde então, linhagens atenuadas de Salmonella que expressam flagelinas quiméricas têm sido utilizadas em diversas formulações vacinais para obtenção de respostas imunológicas mediadas por linfócitos B (MURTHY et al., 2004, NEWTON et al., 1991a; NEWTON et al., 1991b; SMITH et al., 2003; MIZZEL et al., 2003), enquanto poucos estudos voltaram-se para a ativação de respostas imunológicas mediadas por células $\mathrm{T} \mathrm{CD}^{+}$e, sobretudo, por células $\mathrm{T} \mathrm{CD}^{+}$. O primeiro estudo que focalizou a ativação de respostas celulares foi realizado por Verma e colaboradores (1995). Neste estudo dois epítopos, um para células $\mathrm{T} \mathrm{CD}^{+}$e outro para células $\mathrm{T} \mathrm{CD}^{+}$, identificados na exotoxina listeriolisina O (LLO) produzida por Listeria monocytogenes, foram sintetizados contendo ou não resíduos de lisinas flanqueando sua seqüência e inseridos na região central do gene $f l i C d$. Camundongos $\mathrm{BALB} / \mathrm{c}$ foram imunizados, pela via 
intraperitoneal com uma única dose de linhagens atenuadas de Salmonella Dublin que expressavam estes epítopos. Os resultados demonstraram que a formulação contendo os epítopos ladeados por resíduos de lisinas foi capaz de ativar com alta eficiência células $\mathrm{T}$ $\mathrm{CD}^{+}$e linfócitos $\mathrm{T}$ CD8 ${ }^{+}$citotóxicos LLO-específicos. O trabalho mostrou ainda que a ativação dessas populações celulares foi capaz de promover a proteção de animais imunizados contra desafio com L. monocytogenes.

Modificações da proposta inicial, de utilizar linhagens de salmonelas como carregadoras de antígenos heterólogos, incluem a utilização de flagelinas híbridas purificadas. Luna e colaboradores (1997) fusionaram à flagelina de Salmonella peptídeos correspondentes a 4 regiões do antígeno fator de colonização I de E. coli (CFA/I), relacionados à adesão da bactéria ao epitélio intestinal. Camundongos imunizados pela via intraperitoneal com flagelinas híbridas purificadas desenvolveram anticorpos capazes de reconhecer a fímbria. Cuadros e colaboradores (2004), avaliaram a capacidade da flagelina FljB, expressa por $S$. Typhimurium, induzir respostas celulares. Neste trabalho a proteína verde fluorescente (PVF) foi fusionada a porção C-terminal da flagelina. A imunização de animais pela via sub-cutânea, com a proteína híbrida (FljB-PVF) foi capaz de promover a ativação de células $\mathrm{T}$ CD4 ${ }^{+}$e $\mathrm{CD}^{+}$específícas para epítopos da proteína PVF. O trabalho demonstrou ainda, por meio de ensaios in vitro, que a proteína FljB-PVP foi fagocitada com alta eficiência quando comparada a proteína PVP. Esses resultados mostram que em adição as propriedades adjuvantes, flagelinas de salmonelas oferecem a vantagem de transportar o antígeno fusionado e direcioná-lo para APC. Em outro estudo, o efeito adjuvante da flagelina para ativação de respostas celulares foi pesquisado após fusão da ovalbumina (OVA) com a flagelina FljB (HULEATT et al., 2006). Os resultados mostraram que a proteína de fusão foi capaz de ativar células T $\mathrm{CD}^{+}$específicas para OVA. O grupo pesquisou ainda a ativação de células T CD8 ${ }^{+}$ específicas para epítopos contidos em duas proteínas da Listeria monocytogenes. Um fragmento de 235 aminoácidos da listeriolisina O (LLO) e um fragmento de 123 aminoácidos da p60 foram fusionados na flagelina FljB. Os animais imunizados com essa proteína híbrida demonstraram significante resposta de células $\mathrm{T} C \mathrm{CD} 8^{+}$antígeno específica e proteção após desafio com uma linhagem virulenta de L. monocytogenes.

Os efeitos imunoestimuladores de flagelinas de Salmonella foram empregados em uma abordagem terapêutica para tumores de mama induzidos em camundongos pela inoculação da linhagem celular transformada D2F2/E2 (SFONDRINI et al., 2006). Neste trabalho, camundongos $\mathrm{BALB} / \mathrm{c}$ que receberam uma dose intratumoral de flagelina FliC $i$ 
purificada, mostraram regressão do tumor, indicando que a flagelina foi capaz de ativar respostas celulares. Para confirmar a participação de células $\mathrm{T}$ na regressão do tumor, camundongos deficientes na produção dessas células "camundongos nude" foram inoculados com células D2F2/E2. Após receber o tratamento com flagelina, não foi constatada regressão do tumor, confirmando a participação dessa população celular. Neste mesmo trabalho foi demonstrado que a inoculação intratumoral da flagelina promoveu um padrão de citocinas do tipo Th1 que provavelmente favoreceu a resposta celular e a regressão do câncer.

Pesquisas desenvolvidas pelo grupo do pesquisador McSorley (2002), demonstraram o potencial da flagelina para ativação de células $\mathrm{T} \mathrm{CD}^{+}$epecíficas ao antígeno coadministrado, sem a necessidade de fusão à flagelina. Neste trabalho, animais foram imunizados com o peptídeo $\mathrm{T} \mathrm{CD}^{+}$restrito $\mathrm{OVA}_{323-339}$ na ausência ou presença de flagelina FliC $i$. Os resultados revelaram que a ativação e expansão de células T CD4 ${ }^{+}$específicas, foi cerca de 3-10 vezes superior nos animais que receberam a formulação contendo flagelina.

A ativação de células $\mathrm{T} \mathrm{CD}^{+}$representa um ponto fundamental para o desenvolvimento de vacinas efetivas não somente contra a malária, mas também contra qualquer doença causada por patógenos intracelulares. Desse modo, a descoberta de adjuvantes capazes de promover adequada estimulação desta população celular representa um grande passo para o controle de muitas doenças crônicas para as quais, até o momento, os tratamentos foram ineficazes. O presente trabalho representa uma contribuição para a pesquisa e desenvolvimento de vacinas terapêuticas e para a compreensão das propriedades imunoestimuladoras de flagelinas de Salmonella sp. 


\section{2- Objetivo}

O presente projeto tem como principal objetivo avaliar o efeito imunoestimulador de três tipos de flagelinas (FliCi, FliCd e FljB) expressas por linhagens de Salmonella sp., particularmente em relação à ativação de respostas mediadas por células $\mathrm{T} \mathrm{CD}^{+}$. Em uma primeira etapa, utilizamos a ovalbumina como antígeno modelo para explorar o potencial adjuvante das três flagelinas, co-administradas por via parenteral, para a estimulação de células $\mathrm{T} \mathrm{CD}^{+}$específicas. Em uma segunda etapa pesquisamos com maior detalhamento os efeitos adjuvantes da flagelina com efeitos mais promissores (FliCd) frente a um epitopo $\mathrm{T}$ $\mathrm{CD}^{+}$específico da proteína CS de P. yoelli. Para esse fim, animais foram submetidos a regimes de imunização baseados em vacinas de subunidades (flagelina co-administrada ou geneticamente fusionada ao antígeno alvo). Por fim exploramos o potencial vacinal de linhagens atenuadas de $S$. Dublin que expressam flagelinas híbridas geneticamente fusionadas ao epitopo alvo. Os resultados obtidos representam uma importante contribuição à pesquisa das propriedades imunomoduladoras das flagelinas de Salmonella, particularmente na ativação de respostas mediadas por células $\mathrm{T} \mathrm{CD} 8^{+}$citotóxicas. 


\section{3- Material e Métodos}

\section{1- Meios de cultura}

- Para o cultivo das linhagens bacterianas foi usado rotineiramente o meio de LuriaBertani (LB). Quando necessário, foi adicionado ampicilina aos meios na concentração final de $100 \mu \mathrm{g} / \mathrm{mL}$. O meio sólido (LA) foi obtido acrescentando-se $2 \%$ de ágar ao meio LB.

- Para avaliação da mobilidade bacteriana foi utilizado o meio semi-sólido contendo : triptona a $1 \%$, cloreto de sódio $(\mathrm{NaCl})$ a $0,5 \%$, ágar a $0,35 \%$ e o $\mathrm{pH}$ foi ajustado para 7,2. O meio foi autoclavado e quando necessário foi acrescentado ampicilina na concentração final de $100 \mu \mathrm{g} / \mathrm{mL}$.

- Meio SOC utilizado para a recuperação das células após as transformações por eletroporação foi preparado com triptona a $2 \%$, extrato de levedura a $0,5 \%$, cloreto de magnésio a $10 \mathrm{mM}$, sulfato de magnésio a $10 \mathrm{mM}$ e cloreto de sódio a $10 \mathrm{mM}$. Os três últimos sais foram adicionados a partir de soluções estoque concentradas 10 vezes e autoclavadas separadamente. .

- Meio RPMI usado para lavar e manter as células durante os ensaios de resposta celular (ELISPOT e citotoxicidade) foi preparado segundo recomendações do fabricante (SIGMA) e suplementado com penicilina (10 U.I./mL) e estreptomicina (10 $\mu \mathrm{g} / \mathrm{mL})$ (Cultilab). . O meio RPMI foi enriquecido com $1 \%$ ou $10 \%$ de soro fetal bovino inativado (Cultilab), conforme a necessidade. 


\section{2- Tampões, soluções e outros reagentes}

3.2.1- Soluções para eletroforese de proteínas (SDS-PAGE)

- Tampão de amostra - 2\% SDS

4\% 2-mercaptoetanol
10\% glicerol
0,06 M Tris-HCl pH 6,8
4 mM EDTA

Azul de bromofenol adicionado livremente

- Solução estoque de acrilamida - concentração final $30 \%$

$$
\begin{aligned}
& \text { acrilamida 29,0 } \mathrm{g} \\
& \text { bisacrilamida } 1,0 \mathrm{~g}
\end{aligned}
$$

- Solução de persulfato de amônio (APS) - 10\% em água

- Gel de separação (10\%): 1,875 M Tris-HCl, pH 8,8 6 mL

$\begin{array}{ll}0,2 \mathrm{M} \mathrm{Na}_{2} \text { EDTA } & 300 \mu \mathrm{L} \\ \text { acrilamida }(30 \%) & 10 \mathrm{~mL} \\ \text { água bidestilada } & 13,4 \mathrm{~mL} \\ 10 \% \text { SDS } & 300 \mu \mathrm{L}\end{array}$

Após a mistura dos reagentes foi adicionado $300 \mu \mathrm{L}$ de APS $10 \%$ e $25 \mu \mathrm{L}$ de TEMED.

- Gel de empilhamento (5\%): $1 \mathrm{M}$ Tris- $\mathrm{HCl}$ pH 6,81 $88 \mathrm{~mL}$

$\begin{array}{lc}0,2 \mathrm{M} \mathrm{Na}_{2} \text { EDTA } & 150 \mu \mathrm{L} \\ \text { acrilamida (estoque) } & 2,5 \mathrm{~mL} \\ \text { água bidestilada } & 10,3 \mathrm{~mL} \\ 10 \% \text { SDS } & 150 \mu \mathrm{L}\end{array}$

Após a mistura dos reagentes foi adicionado $150 \mu \mathrm{L}$ de APS $10 \%$ e $20 \mu \mathrm{L}$ de TEMED. 
3.2.2- Soluções para coloração do gel

- $\quad 0,25 \%$ Azul de Coomassie Blue R-250

$50 \%$ metanol

$10 \%$ ácido acético

Os géis foram descorados com água sob aquecimento.

3.2.3- Soluções para imunodetecção em membrana de nitrocelulose (immunoblot)

Após a separação das proteínas por eletroforese, essas foram transferidas para um filtro de nitrocelulose (Hybond-C Extra Amershan) em solução de transferência durante 1h com corrente aplicada de $30 \mathrm{~mA}$.

- Tampão de transferência: 39 mM glicina

$20 \%$ metanol

$0,0375 \%$ SDS

$48 \mathrm{mM}$ Tris-HCl

- Soluções para lavagem da membrana:

Tampão salina fosfato (PBS) adicionado de tween 20 a $0,05 \%$

- Soluções para bloqueio e hibridização com o anticorpo:

$2 \%$ de leite desnatado em PBS e 0,05\% de Tween 20 (Sigma)

- Solução de revelação por quimioluminescência para peroxidase:

O reagente de revelação (Kit ECL, Amersham) foi utilizado conforme especificações do fabricante. A solução foi preparada a partir de $500 \mu \mathrm{L}$ do reagente 1 e 500 $\mu \mathrm{L}$ do reagente 2 , misturados no momento do uso. A revelação foi feita em câmara escura e o filme exposto durante cerca 30 minutos submetido à revelação com revelador fotográfico (GBX, Kodak). 
3.2.4 - Soluções utilizadas no ensaio ELISPOT

- Solução para lise de hemácias (ACK)

$$
\begin{aligned}
& 6,60 \mathrm{~g} \mathrm{NH} 4 \mathrm{Cl} \\
& 0,80 \mathrm{~g} \mathrm{KHCO} 3 \\
& 0,03 \mathrm{~g} \mathrm{EDTA} \\
& \text { Água q.s.p. } 1 \mathrm{~L}
\end{aligned}
$$

A solução deve ser esteriliza antes do uso. Utilizar $1 \mathrm{~mL}$ por baço.

- Solução reveladora para peroxidase

$1 \mathrm{mg} / \mathrm{mL}$ de diaminobenzidina (DAB) -(adquirido da SIGMA)

$1 \mu \mathrm{L} / \mathrm{mL}$ de $\mathrm{H}_{2} \mathrm{O}_{2}$

Tris-HCl $50 \mathrm{mM}$ pH 7,5

3.2.5- Soluções para mini-preparação de DNA plasmidiano

\section{- Solução P1}

2,0 mL de EDTA pH $8(0,5 \mathrm{M})$

2,5 mL de Tris HCL pH 8 (2M)

Água milli-Q qsp $100 \mathrm{~mL}$

Autoclavar $20 \min$ à $120^{\circ} \mathrm{C}$

Depois de esfriar agregar RNAse para uma concentração final de $100 \mu \mathrm{g} / \mathrm{mL}$, a partir da solução estoque de RNAse a $10 \mathrm{mg} / \mathrm{mL}$. Armazenar à $4^{\circ} \mathrm{C}$.

- Solução P2 (preparar no momento do uso)

$200 \mu \mathrm{L} \mathrm{NaOH} 10 \mathrm{~N}$

$500 \mu \mathrm{L}$ SDS $20 \%$

Água milli-Q qsp $10 \mathrm{~mL}$ 
- Solução P3

29,4 g KOAc

11,4 mL ácido acético glacial

Água milli-Q qsp 100 mL

Homogeneizar e autoclavar 20 min à $120^{\circ} \mathrm{C}$.

Armazenar à $4^{\circ} \mathrm{C}$

- $\mathrm{NaOH} 10 \mathrm{~N}$

$12 \mathrm{~g}$ de $\mathrm{NaOH}$

$30 \mathrm{~mL}$ de àgua milli-Q

- SDS $20 \%$

$6 \mathrm{~g}$ de dodecilsulfato de sódio (SDS)

$30 \mathrm{~mL}$ de àgua milli-Q

- PEG $\mathrm{NaCl}$

2 g polyetilenoglicol (Peg 8000) 20\%

$1,461 \mathrm{~g} \mathrm{NaCl} 2,5 \mathrm{M}$

10 mL de àgua milli-Q

3.2.6- Solução Salina fosfato (PBS) $10 \mathrm{X}$

$\begin{array}{lc}\mathrm{NaCl} & 80 \mathrm{~g} \\ \mathrm{KCl} & 2 \mathrm{~g} \\ \mathrm{Na} 2 \mathrm{HPO} 4 & 18 \mathrm{~g} \\ \mathrm{KH} 2 \mathrm{PO} 4 & 3 \mathrm{~g} \\ \text { Água destilada q.s.p. } & 1 \mathrm{~L} \\ \text { Ajustar o pH para 7,4 }\end{array}$


3.2.7- Solução PBS 1X

$\begin{array}{ll}\text { PBS 10X } & 100 \mathrm{~mL} \\ \text { Água q.s.p. } & 1 \mathrm{~L}\end{array}$

3.2.8- Solução bicarbonato de sódio $0,1 \mathrm{M}$ - administrada a camundongos por via oral $(0,5 \mathrm{~mL})$ antes das imunização por via oral

$8,4 \mathrm{~g} \mathrm{NaHCO}_{3}$

Água q.s.p. 1L

Esterilizar por filtração em filtro $0,22 \mu \mathrm{m}$

\section{3- Linhagens bacterianas e plasmídeos}

\subsection{1- Linhagens bacterianas.}

As linhagens bacterianas utilizadas no presente trabalho estão descritas na tabela 1 . As diferentes linhagens de Salmonella foram crescidas em meio LB sob agitação de 200 rpm e temperatura de $37^{\circ} \mathrm{C}$. 
Tabela 1: Linhagens de Salmonella sp. utilizadas no presente trabalho

\begin{tabular}{|c|c|c|}
\hline Linhagens & Caracteristicas lenotipicas & Relerencia \\
\hline S.. Dublin SL5928 & aro $A^{-} ; f l i C(\mathbf{i}):$ Tn10; não móvel & Newton et al., 1989 \\
\hline S. Dublin SL5930 & SL5928 com o pLS408; móvel & Newton et al., 1989 \\
\hline S. Thyphimurium LDV322 & $\operatorname{aro} A^{-} ; f l j B:: M u d j ; m o ́ v e l$ & Massis et al., 2007 \\
\hline S.. Thyphimurium LDV323 & aro $\mathrm{A}^{-} ; f l i C(\mathbf{i}):: \operatorname{Tn} 10 ;$ móvel & Massis et al., 2007 \\
\hline S. Dublin LDV500 & SL5928 com o pLSCS; móvel & Presente estudo \\
\hline S. Dublin LDV501 & SL5928 com o pLSCSL; não móvel & Presente estudo \\
\hline
\end{tabular}

\subsection{2- Plasmídeos}

- pLS408 (6,0 kb) - derivado do pUC19, contendo um inserto de 3,35 kb de DNA gênômico de Salmonella Muenchen onde se encontra o gene fliC (H1-d) com uma deleção de 48 pb na região correspondente à porção hipervariável da flagelina. Este vetor apresenta um sítio único EcoRV na região central do gene, facilitando a clonagem do epitopo de interesse, e possui o gene que confere resistência à ampicilina, marcador importante na seleção dos transformantes (NEWTON et al., 1989) (Figura 2). 


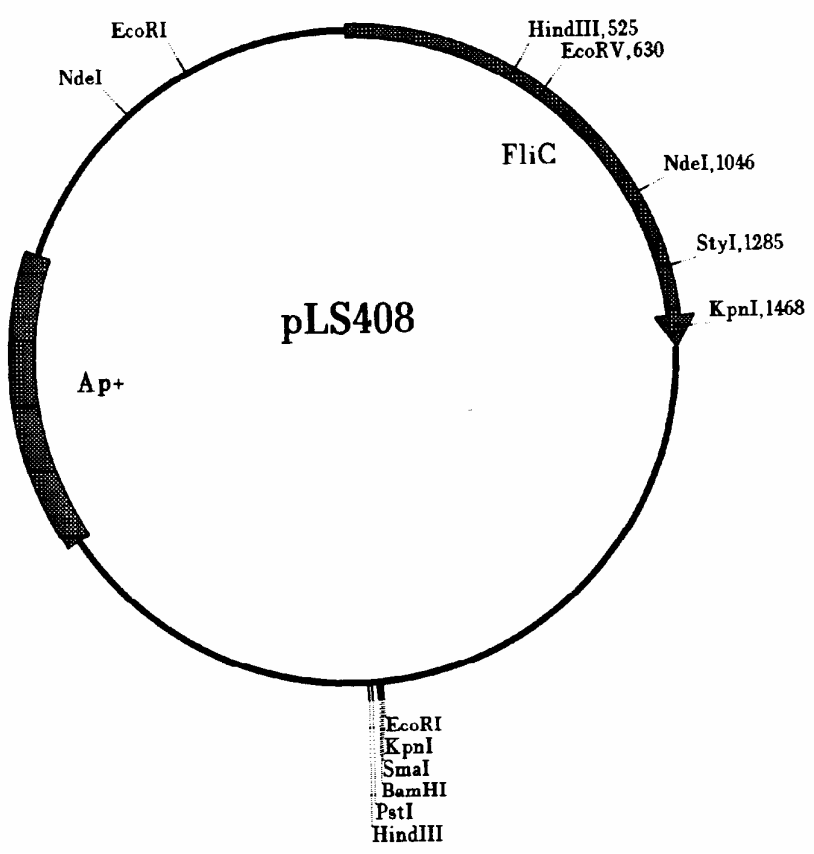

Figura 2: Representação esquemática do vetor pLS408. O plasmídeo é derivado do pUC19 (Newton et al., 1989) com um inserto de DNA cromossômico de $S$. Muenchen que contém o gene FliC (H1-d) que codifica a flagelina com uma deleção de 48 pb que origina um sítio único EcoRV na região hipervariável do gene.

\section{4- Oligonucleotídeos sintéticos, anticorpos e outros reagentes biológicos}

- Oligonucleotídeos, complementares entre si, codificando o epitopo específico para células $\mathrm{T}$ CD8+, SYVPSAEQI $\left(\mathrm{CS}_{280-288}\right)$ foram sintetizados por Integrated DNA Technologies (IDT)(tabela 2). Os oligonucleotídeos foram sintetizados de modo a conter ou não dois resíduos de lisina flanqueando-os. Estudos anteriores demonstraram que resíduos de lisinas flanqueando uma seqüência de aminoácidos levam ao aumento da imunogenicidade da seqüência flanqueada, possivelmente por facilitar a excisão proteolítica do epitopo no compartimento endossomal de células apresentadoras de antígenos (VERMA et al., 1995). 
TTabela 2: Oligonucleotídeos sintéticos representando o epitopo $\mathbf{T ~ C D 8}^{+}$da proteína CS.

\begin{tabular}{l|l|l}
\hline Denominação & Seqüência & Pb \\
\hline CS & 5'-AgCTATgTgCCgAgCgCggAACAgATT -3' $^{\prime}$ & 27 \\
\hline CS ver & 5'AATCTgTTCCgCgCTCggCACATAgCT -3' $^{\prime}$-AATCA & 27 \\
\hline CSL & 5'-AAAAAAAgCTATgTgCCgAgCgCggAACAgATTAAAAAA-3' & 39 \\
\hline CSL ver & 5'-TTTTTTAATCTgTTCCgCgCTCggCACATAgCTTTTTTT -3' $^{\prime}$ & 39 \\
\hline
\end{tabular}

- Anticorpos anti-flagelina FliCd foram adquiridos da Difco e usados nos ensaios de imunodetecção na diluição de 1:2.000. Anticorpos anti-IgG de camundongo conjugado a peroxidase produzidos em coelho foram adquiridos da SIGMA e utilizados na diluição 1:5.000 nos ensaios de Western blot.

- Estreptoavidina conjugada com peroxidade foi adquirida da SIGMA e usada nos ensaios de ELISPOT na diluição 1:800.

- CFSE ou CFDA SE (carboxyfluorescein fluorescein diacetate, succinimidyl ester) The Vybrant ${ }^{\circledR}$ CFDA SE Cell Tracer Kit, adquirido da Invitrogen e utilizado nas concentrações de $1 \mu \mathrm{M}$ e $10 \mu \mathrm{M}$.

\section{5- Transformação de bactérias}

As células competentes para eletroporação foram preparadas como recomendado pelo fabricante do aparelho (Gene-Pulser, Biorad). O procedimento foi iniciado com a diluição de um pré-inóculo de $5 \mathrm{~mL}$ em $500 \mathrm{~mL}$ de meio LB deixando-se crescer até D.O. de 0,5 (600 nm). As células foram mantidas em gelo e, em seguida, centrifugadas durante 15 minutos a 6.000 x g. O precipitado foi ressuspendido em $500 \mathrm{~mL}$ de água MilliQ gelada com $10 \%$ de glicerol e o tubo centrifugado como anteriormente. As células foram lavadas novamente em água gelada com $10 \%$ de glicerol $(250 \mathrm{~mL})$, centrifugadas e ressuspensas em 
$50 \mathrm{~mL}$ de água gelada com $10 \%$ de glicerol. Após nova centrifugação, as células foram ressuspensas em $1 \mathrm{~mL}$ de água gelada e glicerol a $10 \%$ e o volume final distribuído em tubos com $40 \mu \mathrm{L}$ cada e congelados rapidamente. As alíquotas foram estocadas a $-70^{\circ} \mathrm{C}$. A cada alíquota de células foi misturado de 1 a $2 \mu \mathrm{L}$ de DNA (aproximadamente $25 \mathrm{ng}$ ) e a mistura transferida para uma cuba de eletroporação. O pulso elétrico utilizou resistência de 200 Ohms, capacitância de $25 \mu \mathrm{F}$ e $2.500 \mathrm{~V}$ (condições recomendadas pelo fabricante). Imediatamente após o pulso foi adicionado $1 \mathrm{~mL}$ de meio SOC diretamente na cuba. Em seguida, o material foi transferido para um tubo de ensaio e incubado a $37^{\circ} \mathrm{C}$ durante 60 minutos, sob agitação. As células foram plaqueadas em meio LB, acrescido de ampicilina, e incubadas a $37^{\circ} \mathrm{C}$ durante aproximadamente 12 horas.

\section{6- Inserção do epitopo T CD8 -SYVPSAEQI- na região hipervariável do gene fliCd}

Os pares de oligonucleotídeos, especificando o epítopo CS, foram misturados (10 $\mathrm{ng} / \mu \mathrm{l}$ cada), deixados em um banho a $80^{\circ} \mathrm{C}$, e mantidos no banho até a temperatura de $35^{\circ} \mathrm{C}$ (essa etapa permitiu o anelamento dos oligos). Em seguida o DNA dupla fita foi inserido no gene $f l i C d$ de $S$. Muenchen presente no plasmídeo pLS408. A inserção foi realizada em um único sítio ECORV localizado na região hipervariável do gene (Newton et al, 1989) (Figura 2). A clonagem foi confirmada por enzimas de restrição e sequenciamento do gene fliCd através da técnica de interrupção de síntese com dideoxinucleotídeos marcados com fluorocromos. Utilizou-se o seqüenciador automático (ABI 377, Perkin-Elmer Applied Biossystems) disponível no departamento de Microbiologia e reagentes do kit comercial "Big Dye terminator DNA sequecing" (Perkin-Elmer Applied Biosystem) e o oligonucleotídeo iniciador Seq IV (5'- CCA GGT GCC TAC ACC CCG - 3') obtido da Integrated DNA Technologies (IDT). 


\section{7- Caracterização da expressão de flagelina pelas linhagens construídas}

\subsection{1- Ensaios de Mobilidade.}

As mobilidades das diferentes linhagens de Salmonella foram determinadas em placas contendo meio semi-sólido. Cada placa foi semeada com uma linhagem, aplicada na forma de ponto no centro da placa. A leitura foi realizada após $24 \mathrm{~h}$ em um cultivo à $37^{\circ} \mathrm{C}$ medindo-se o diâmetro do halo de crescimento em centímetros.

\subsection{2- Preparação de flagelinas purificadas.}

As linhagens de Salmonella utilizadas para a extração do flagelo foram semeadas em $50 \mathrm{~mL}$ de meio LB com $100 \mu \mathrm{g} / \mathrm{mL}$ de ampicilina e incubadas a $37^{\circ} \mathrm{C}$ com agitação de $80 \mathrm{rpm}$ durante $16 \mathrm{~h}$. As células foram coletadas por centrifugação a $6.000 x$ g por 15 minutos, e ressuspensas em $2 \mathrm{~mL}$ de PBS. A suspensão bacteriana foi agitada em agitador tipo "vortex" em 4 ciclos de 2 min, com intervalos de 1 min no gelo. Após a remoção das células (centrifugação a $8.000 \mathrm{x} \mathrm{g}, 15$ min a $4^{\circ} \mathrm{C}$ ) o sobrenadante foi coletado em frasco tipo "corex". Foi adicionado ao material 3 a 4 volumes de acetona gelada para precipitação da flagelina presente. Após 30 minutos de repouso a $-20^{\circ} \mathrm{C}$, o material foi centrifugado a $13.000 \mathrm{x}$ g por 15 minutos e o precipitado ressuspenso em aproximadamente $0,5 \mathrm{~mL}$ de PBS. Todas as flagelina utilizadas para os ensaios imunológicos foram submetidas a aquecimento a $65^{\circ} \mathrm{C}$ por 30 minutos, para promover a despolimerização do filamento flagelar extraído, e em seguida foram purificadas de LPS com a coluna Detoxi-Gel ${ }^{\mathrm{TM}}$ Endotoxin Removing Gel, Pierce, utilizada conforme instruções do fabricante.

\subsection{3- Preparação de lisados celulares para gel de poliacrilamida.}

As linhagens foram cultivadas, até fase logarítmica, a $37^{\circ} \mathrm{C}$ com agitação e a D.O. foi medida a $600 \mathrm{~nm}$. O volume da cultura a ser usado para o preparo do lisado foi calculado segundo a fórmula: 


$$
\mathrm{X} \mathrm{mL}=4.8 \text { / D.O.600 }
$$

As células foram recolhidas após centrfugação a 1.500 x g durante 15 minutos. $\mathrm{O}$ precipitado foi ressuspenso em $350 \mu \mathrm{L}$ de tampão de amostra e fervido durante 5 minutos. Alíquotas de 10 a $15 \mu \mathrm{L}$ foram aplicadas em cada poço do gel de poliacrilamida.

\subsection{4- Imunodetecção em filtro de nitrocelulose (Western blot).}

Confirmada a fusão genética dos oligonucleotídeos, o plasmídeo foi introduzido por eletroporação na linhagem SL5928 para confirmação da expressão das flagelinas híbridas. As linhagens de Salmonella utilizadas para a extração do flagelo foram semeadas em $50 \mathrm{~mL}$ de meio LB com $100 \mu \mathrm{g} / \mathrm{mL}$ de ampicilina e incubadas a $37^{\circ} \mathrm{C}$ com agitação de $80 \mathrm{rpm}$ durante 16h e depois submetidas ao protocolo para extração de flagelina da superfície flagelar. A quantidade total de proteínas foi determinada usando-se o método de BSA Pierce $\left(\mathrm{BCA}^{\mathrm{TM}}\right.$ Protein Assay Reagent A - Pierce) e a pureza determinada em gel de poliacrilamida a 12,5\% com coloração por Coomassie Blue R-250. Após a separação das proteínas por eletroforese, estas foram transferidas para um filtro de nitrocelulose (Hybond-C Extra Amershan). Os sítios onde a proteína não ligou foram bloqueados por $2 \mathrm{~h}$ a $37^{\circ} \mathrm{C}$ com uma solução de bloqueio (leite 5\% em PBS-T) e em seguida, a membrana foi tratada com anticorpo anti-flagelina $d$ na diluição 1:3000 por $2 \mathrm{~h}$ a $37{ }^{\circ} \mathrm{C}$. Após quatro lavagens com PBS-T foi adicionado imunoglobulina de coelho conjugada à peroxidase reativa contra $\operatorname{IgG}$ de camundongo na diluição 1:5000 e deixado por $2 \mathrm{~h}$ a $37{ }^{\circ} \mathrm{C}$. Após novo ciclo de lavagens a membrana foi submetida à revelação por quimioluminescência com o reagente de revelação (Kit ECL, Amersham), de acordo com especificações do fabricante. A revelação foi feita em câmara escura e o filme foi exposto durante cerca 30 min e submetido à revelação com revelador fotográfico (GBX, Kodak). 


\section{8- Estudos imunológicos}

\subsection{1- Animais.}

As linhagens de camundongos isogênicos foram obtidas junto ao Biotério de Isogênicos da Parasitologia do Instituto de Ciências Biomédicas da USP da USP: BALB/c e C57BL/6. Os animais utilizados tinham entre 6 a 8 semanas de idade.

\subsection{2- Protocolos de imunização.}

\subsubsection{1 - Preparação das linhagens bacterianas para imunizações.}

As linhagens foram semeadas em meio LB, com ou sem ampicilina, a partir dos estoques a $-70 \mathrm{C}$ e incubadas durante uma noite a $37^{\circ} \mathrm{C}$, com agitação. A partir desse inoculo foi realizado um cultivo, com diluição de $1: 100$ e crescidos a $37^{\circ} \mathrm{C}$, com agitação durante 45h. As células foram lavadas duas vezes com solução salina a 0,09\% e ressuspensas na concentração de $2 \times 10^{10}$ células $/ \mathrm{mL}$.

\subsubsection{2- Antígenos, peptídeos e adjuvantes utilizados nas imunizações.}

- Ovalbumina (OVA) (Sigma Chemical, St. Louis Louis, Mo, USA) foi administrada na dose de $12 \mu \mathrm{g} / \mathrm{animal}$, por via sub-cutânea.

- Os peptídeos sintéticos $\mathrm{H}-2 \mathrm{~K}^{\mathrm{b}}$-restrito SIINFEKL (OVA $\left.257-264\right)$ e $\mathrm{H}-2 \mathrm{~K}^{\mathrm{d}}$-restrito SYVPSAEQI ( $\left.\mathrm{CS}_{280-288}\right)$ adquiridos da Peptide Specialtry Laboratoreies (PSL GmbH), Heidelbergue, Alemanha, foram utilizados na dose de $25 \mu \mathrm{g} / \mathrm{animal}$, administrados pelas vias sub-cutânea ou nasal. 
- Adjuvante Completo de Freund (CFA- Sigma Chemical, St. Louis, Mo, USA), misturado na proporção 1:1 (vol/vol) para obter uma emulsão, foi utilizado nos protocolos de imunização por via sub-cutânea (s.c.).

Os animais foram imunizados pelas vias: oral (v.o), nasal (i.n.) e sub-cutânea (s.c.). Os regimes vacinais adotados nas diferentes imunizações foram os seguintes:

- Via sub-cutânea: $5 \mu \mathrm{g}$ de flagelina FliCd purificadas ou $15 \mu \mathrm{g}$ de flagelinas híbridas purificadas, administradas em um volume máximo de $200 \mu \mathrm{L}$. Para esta via foi adotado o esquema de imunização em 2 doses, administradas em 0 e 28 dias.

- Via nasal: $5 \mu \mathrm{g}$ de flagelinas FliCd purificadas ou $15 \mu \mathrm{g}$ de flagelinas híbridas purificadas, obtidas a partir das diferentes linhagens construídas e administradas em um volume máximo de $10 \mu \mathrm{L}$. Foi adotado o esquema de 2 doses, administradas nos dias 0 e 28.

- Via oral : $1 \times 10^{10}$ bactérias em $0,5 \mathrm{~mL}$ bicarbonato de sódio 0,2 M. As alíquotas foram administradas com auxílio de cânula metálica curva com esfera na ponta (gavage). Foi adotado o esquema de imunização baseado em 3 doses, administradas nos dias $\mathrm{D}, \mathrm{D}+21$ e $\mathrm{D}+35$. Onde $\mathrm{D}=$ dia da primeira dose

\subsection{3- Ensaios celulares}

\subsubsection{1- ELISPOT (Enzyme-linked immunosorbent spot).}

O ensaio ELISPOT foi realizado para detectar células produtoras de IFN- $\gamma$ específicas para os peptídeos $\mathrm{OVA}_{257-264}$ e $\mathrm{CS}_{280-288}$. Esse ensaio detecta citocinas liberadas em resposta a estímulos in vitro no nível de uma única célula e foi realizado segundo metodologia descrita anteriormente (MIYAHIRA et al, 1994). Após sete dias da última dose do esquema de imunização, os animais foram submetidos à eutanásia, seus baços retirados e 
as células utilizadas para o ensaio. $2 \times 10^{5}$ células derivadas do baço ou do sangue de camundongos imunizados foram adicionadas em cada poço de uma placa de 96 poços (Millipore), previamente sensibilizada com anticorpo monoclonal de captura anti-IFN- $\gamma$ de rato (BD, Pharmingen). $\mathrm{O}$ anticorpo de captura foi utilizado a concentração final de $10 \mu \mathrm{g} / \mathrm{mL}$. As células foram incubadas por $24 \mathrm{~h}$ a $37^{\circ} \mathrm{C}$ em uma atmosfera de $5 \%$ de $\mathrm{CO}_{2}$ na ausência ou presença do estímulo ( $1 \mu \mathrm{g} / \mathrm{mL}$ de peptídeo). No dia seguinte, as células foram desprezadas, a placa lavada com 3X com PBS e 5X com PBS-T e incubada com anticorpo monoclonal antiIFN- $\gamma$ de camundongo biotinilado (BD, Pharmingen) na concentração final de $2 \mu \mathrm{g} / \mathrm{mL}$. Após uma noite a $4{ }^{\circ} \mathrm{C}$, a placa foi novamente lavada e adicionou-se estreptavidina peroxidase (SIGMA). Após $2 \mathrm{~h}$ de incubação a temperatura ambiente, a placa foi lavada e submetida à revelação com uma solução contendo diaminobenzidina por 30 minutos. Os "spots" foram contados com auxílio do equipamento ImmunoSpot (Cellular Technology, Ltd.). Em alguns ensaios a cultura de células foi enriquecida com linfócitos $\mathrm{T} \mathrm{CD}^{+}(>90 \%)$ usando partículas magnéticas em um "AutoMacs cell separator" (Miltenyi Biotec, Auburn, CA, USA). Células de camundongos não imunizados $\left(10^{5}\right.$ células/poço) foram adicionadas aos poços contendo os linfócitos purificados para servir de célula apresentadora de antígenos (APC).

\subsubsection{2- Citotoxicidade in vivo.}

O ensaio de citotoxicidade in vivo foi realizado para verificar a presença de células $\mathrm{T}$ CD8+ citotóxicas, específicas para os peptídeos $\mathrm{OVA}_{257-264}$ ou $\mathrm{CS}_{280-288}$, em animais imunizados, de acordo com metodologia descrita por (BARBER et al., 2003). Após sete dias da imunização, um grupo de animais não imunizado foi submetido à eutanásia, seus baços

retirados e as células utilizadas para o ensaio. Cerca de $2 \times 10^{8}$ células foram incubadas com 1 $\mu \mathrm{M}$ ou $10 \mu \mathrm{M}$ de CFSE em PBS, por 15 minutos a $37^{\circ} \mathrm{C}$. Após a incubação, as células foram lavadas e ressuspensas em meio RPMI acrescido de $1 \%$ de soro fetal bovino (RPMI-1\%). Ao tubo contendo a população de células marcadas com $10 \mu \mathrm{M}$ de CFSE foi adicionado $25 \mu \mathrm{M}$ do peptídeo de interesse, e incubado por 40 minutos a $37^{\circ} \mathrm{C}$. Após este período as células foram lavadas com meio RPMI-1\% para remoção do peptídeo e contadas. Quantidades iguais 
das duas populações de células marcadas foram misturadas e centrifugadas a 1.700xg. O precipitado de células foi ressuspenso em RPMI (sem soro fetal bovino) de modo a conter 2-4 x $10^{7}$ células/200 $\mu \mathrm{L}$ e injetado em todos os animais imunizados e no grupo não imunizado, pela via do plexo retro orbital. No dia seguinte, todos animais foram submetidos a eutanásia e as células dos baços coletadas. As células foram ressuspensas em PBS e examinadas por citometria de fluxo para detecção de fluorescência emitida pelas duas populações celulares utilizando o aparelho FACScalibur ${ }^{\mathrm{ma}}$ (Becton Dickinson, Mountain View, CA). Foram contados 10.000 eventos da população marcada com $1 \mu \mathrm{M}$. Os dados foram analisados pelo programa "FlowJo" para a determinação das porcentagens de células marcadas com $1 \mu \mathrm{M}$ ou $10 \mu \mathrm{M}$ de CFSE. 


\section{4 - Resultados}

\subsection{Efeito adjuvante das flagelinas FliCd, FliCi e FljB de Salmonella sp. na ativação de resposta imune celular específica para ovalbumina}

Com o objetivo de avaliar o potencial adjuvante diferencial de três sorotipos de flagelinas expressas por linhagens atenuadas de Salmonella sp. na ativação de respostas imunológicas mediadas por células $\mathrm{T} \mathrm{CD}^{+}$, camundongos da linhagem C57BL/6 foram imunizados, pela via s.c., com duas doses de OVA $(12 \mu \mathrm{g})$ e $5 \mu \mathrm{g}$ de cada uma das flagelinas testadas (FliCd, FliCi ou FljB). A ativação de resposta celular foi medida inicialmente pela presença de células produtoras de IFN- $\gamma$ específicas para o peptídeo MHC classe I restrito OVA $_{257-264}$, por meio de ELISPOT de células totais de baço e de sangue dos animais imunizados. Nas figuras 3A e 3B visualizamos a ativação de resposta celular específica ao epitopo $\mathrm{T} \mathrm{CD}^{+}$da OVA pelos três sorotipos de flagelinas. A flagelina FliCd apresentou melhor atividade adjuvante dentre as flagelinas estudadas e foi capaz de estimular um maior número de células produtoras de IFN- $\gamma$ quando comparadas aos animais que receberam apenas OVA. Os resultados mostram que a flagelina FliCd foi capaz de estimular células T específicas para o epitopo $\mathrm{T} \mathrm{CD}^{+}$restrito $\mathrm{OVA}_{257-264}$, embora em menor número que o encontrado em animais imunizados com o peptídeo e o adjuvante CFA, previamente descrito como capaz de ativar respostas celulares específicas (SHIBAKI e KATZ, 2002).

Para confirmar a ativação de células $\mathrm{T}_{\mathrm{CD}}{ }^{+}$específicas, realizamos o ensaio ELISPOT apenas com células $\mathrm{T} \mathrm{CD}^{+}$purificadas do baço de animais imunizados. $\mathrm{O}$ efeito adjuvante da flagelina FliCd, bem como das flagelinas FliCi e FljB na ativação de células T $\mathrm{CD}^{+}$foi evidenciado de forma mais clara quando empregamos células $\mathrm{T} \mathrm{CD} 8^{+}$de animais imunizados com as diferentes formulações vacinais e estimuladas in vitro com o peptídeo $\mathrm{OVA}_{257-264}$. Os resultados mostrados na figura 4 confirmam que os três tipos de flagelinas foram capazes de potencializar a resposta de células $\mathrm{T} \mathrm{CD} 8^{+} \mathrm{OVA}$-específicas. Como controle positivo foi utilizado um grupo de animais imunizado com OVA e CFA. 
(A)

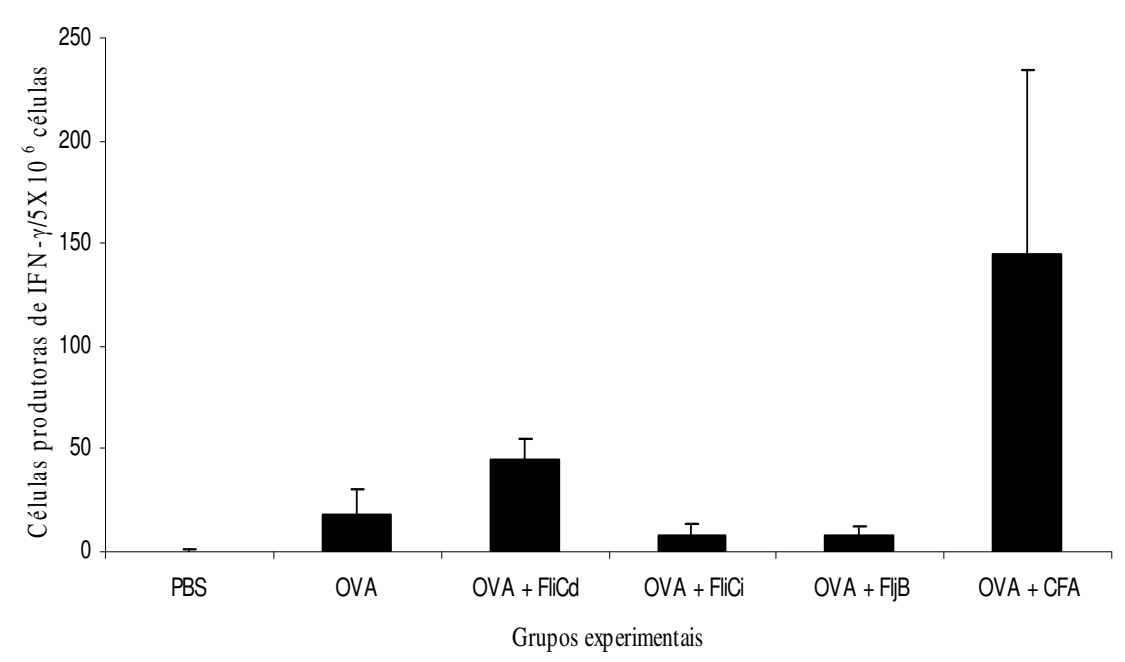

(B)

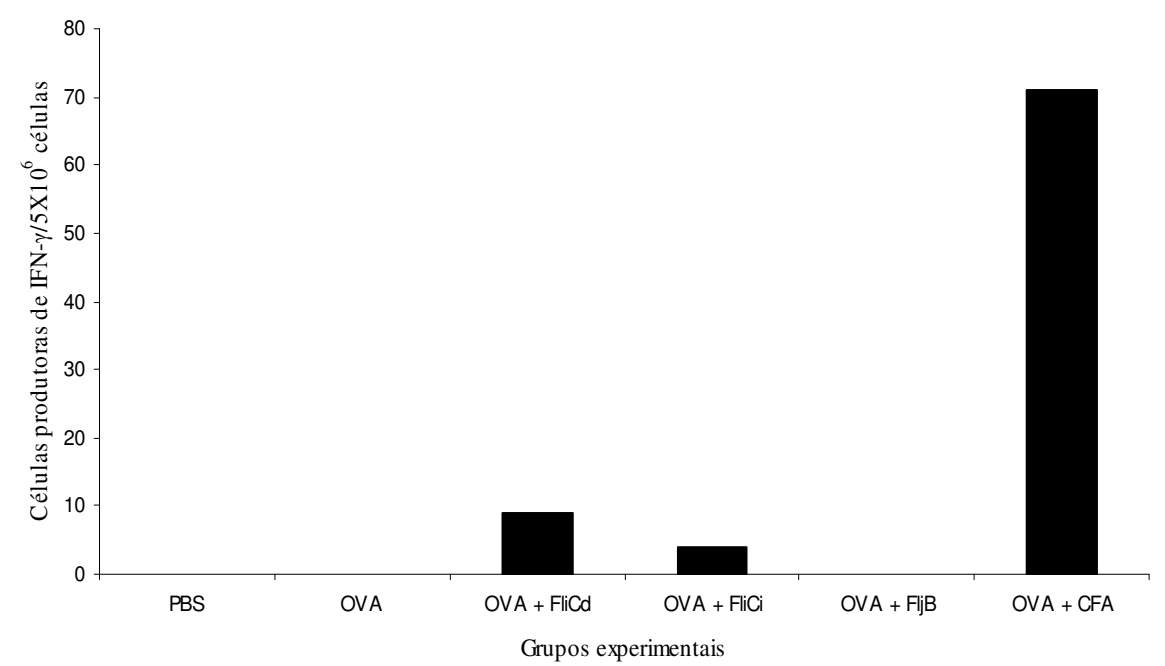

Figura 3: Resposta imune celular OVA-específica analisada por ELISPOT de células totais derivadas do baço (A) e sangue (B) dos animais imunizados. As respostas imunológicas foram examinadas em camundongos C57BL/6 após imunização por via s.c. Os animais receberam duas doses de tampão salina fosfato (PBS), ovalbumina (OVA), OVA co-administrada à flagelina FliC $d$ (OVA + FliCd), OVA co-administrada à flagelina $\mathrm{FliC} i(\mathrm{OVA}+\mathrm{FliCi})$ ou OVA co-administrada à flagelina $\mathrm{FljB}(\mathrm{OVA}+\mathrm{FljB})$. Um grupo de animais foi imunizado da mesma forma com OVA emulsificada com o adjuvante CFA (OVA + CFA). Os resultados referem-se ao número de células produtoras de IFN- $\gamma$ após estimulação in vitro com o peptídeo OVA $257-264$ conforme descrito na metodologia. Os dados apresentados representam a média de dois experimentos independentes, realizados em duplicata, com grupos de quatro animais. 


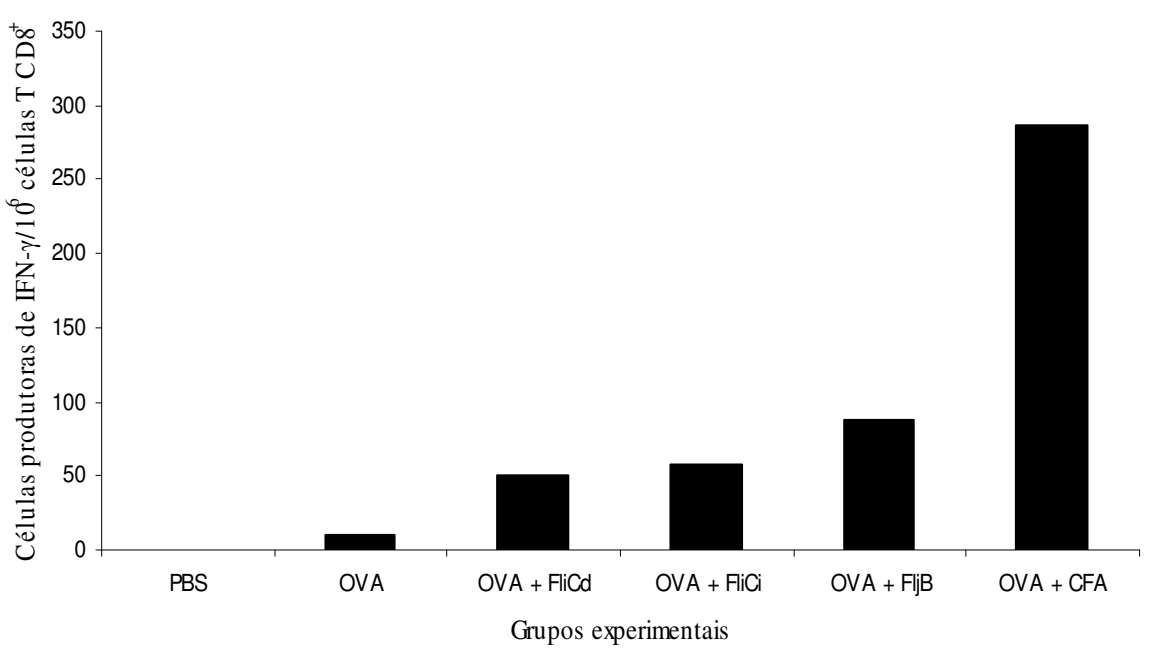

Figura 4: Ativação de respostas OVA-específicas mediadas por células $\mathrm{T}$ CD8 ${ }^{+}$produtoras de IFN- $\gamma$. Camundongos C57BL/6 receberam duas doses por via s.c. de tampão salina fosfato (PBS), ovalbumina (OVA), ovalbumina co-administrada à flagelina FliCd (OVA + FliCd), ovalbmina co-administrada à flagelina FliC $i$ $(\mathrm{OVA}+$ FliCi) ou Ovalbumina co-administrada à flagelina FljB (OVA + FljB). Um grupo de animais foi imunizado da mesma forma com ovalbumina emulsificada com o adjuvante CFA (OVA + CFA).Células T CD8 ${ }^{+}$ foram purificadas do baço, estimuladas in vitro com o peptídeo $\mathrm{OVA}_{257-264} \mathrm{e}$ analisadas para produção de IFN- $\gamma$ em ELISPOT. Os dados apresentados referem-se à mistura de células obtidas de 4-5 animais por grupo.

Um ensaio de citotoxicidade in vivo foi realizado para demonstrar a capacidade de células $\mathrm{T} \mathrm{CD}^{+}$ativadas promover a lise de células marcadas com o antígeno alvo. Grupos de 4 camundongos da linhagem C57BL/6 foram imunizados por via s.c. com duas doses de OVA $(12 \mu \mathrm{g})$ e $5 \mu \mathrm{g}$ de cada uma das flagelinas FliCd, FliCi ou FljB. Após a imunização, todos os animais receberam, por i.v., $2 \times 10^{7}$ células marcadas com CFSE e cobertas com o peptídeo $\mathrm{OVA}_{257-264}$. Após $24 \mathrm{~h}$ os animais foram submetidos à eutanásia e as células marcadas foram recuperadas a partir do baço e contadas com auxílio de um citômetro de fluxo. Os resultados apresentados da figura 5 mostram que as flagelinas FliC $d$ e FliC $i$ foram capazes de destruir as células alvo, confirmando os resultados obtidos no ELISPOT que detectou células T CD8 ${ }^{+}$ produtoras de IFN- $\gamma$ OVA-específicas. Por outro lado, a flagelina FljB não foi capaz de promover ativação do efeito citotóxico, embora linfócitos $\mathrm{T} \mathrm{CD}^{+}$secretores de IFNespecíficos para o epitopo $\mathrm{OVA}_{257-264}$ tenham sido detectados no ensaio de ELISPOT. Os 
resultados demonstram que as formulações vacinais baseadas nas flagelina $\mathrm{FliC} d$ e $\mathrm{FliC} i$ foram capazes de gerar linfócitos $\mathrm{T}$ citotóxicos funcionais, capazes de promover a lise específica de células marcadas com o epitopo MHC classe I restrito OVA257-264.

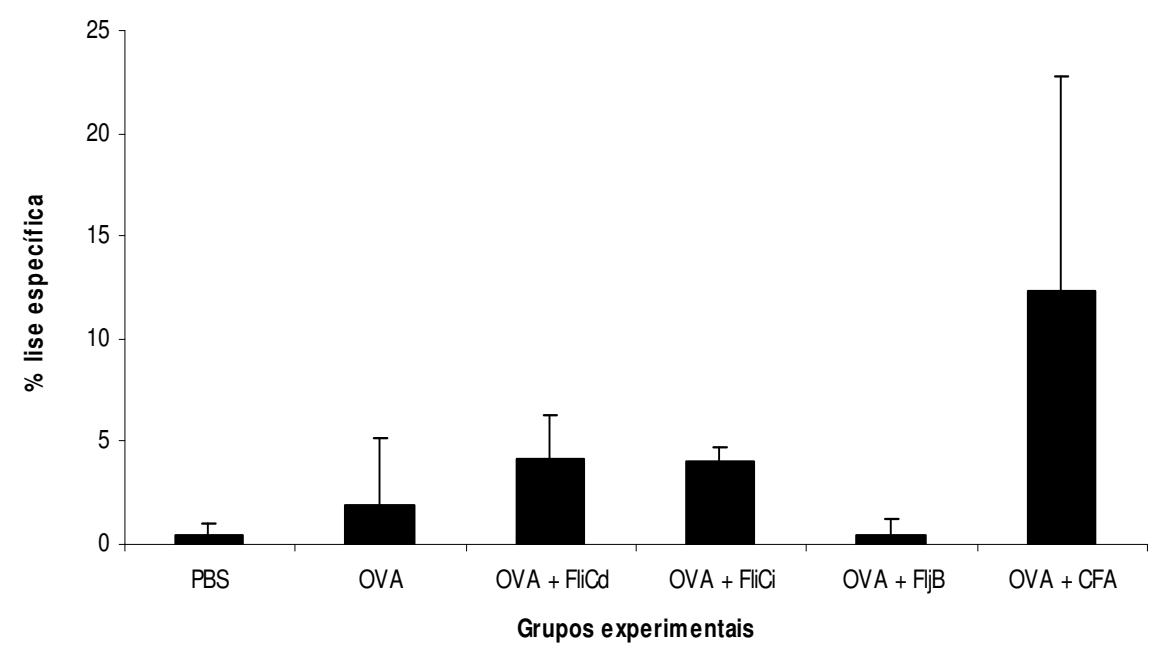

Figura 5: Avaliação da citotoxicidade in vivo em camundongos imunizados com OVA. Camundongos C57BL/6 receberam duas doses de tampão salina fosfato (PBS), ovalbumina (OVA), OVA co-administrada à flagelina FliC $d$ (OVA + FliCd), OVA co-administrada à flagelina FliCi (OVA + FliCi), OVA co-administrada à flagelina

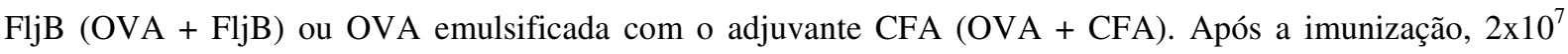
células-alvo foram tranferidas para todos os camundongos e após $24 \mathrm{~h}$ recuperadas e contadas em citômetro de fluxo. Os resultados representam o percentual de células mortas em $2 \times 10^{7}$ células-alvo. Os resultados correspondem à média de quatro animais por grupo.

\subsection{Clonagem do epitopo $\mathrm{CS}_{280-288}$ na região hipervariável do gene que codifica para a flagelina FliCd de Salmonella sv. Dublin}

Os resultados iniciais obtidos com OVA, empregada como antígeno alvo, revelaram que a flagelina FliCd apresentou o maior potencial adjuvante entre as três flagelinas de salmonelas testadas. Com o objetivo de avaliar o potencial imunoestimulador da flagelina 
FliCd para ativação de células $\mathrm{T} C \mathrm{CD} 8^{+}$específicas para um antígeno de importância clínica, escolhemos como antígeno alvo um peptídeo sintético (pCS) correspondente a um epitopo T $\mathrm{CD}^{+}$da proteína circunsporozoíta (CS) de Plasmodium yoelii.

Além de empregarmos a flagelina FliC $d$ como adjuvante co-administrado, decidimos também avaliar seu o potencial adjuvante após a fusão genética com o peptídeo pCS, obtida após a clonagem no gene fliCd do peptídeo CS ladeado ou não por dois lisinas, uma característica importante para um melhor processamento e apresentação do epítopo heterólogo por células apresentadoras de antígenos. Na tabela 2 estão representados oligonucleotídeos sintéticos utilizados para a clonagem do epitopo pCS na flagelina FliCd. Os oligonucleotídeos foram inseridos no sítio único para a enzima de restrição EcoRV presente na região central do gene fliCd (Figura 6) A inserção foi confirmada por perda do sítio de restrição e por sequienciamento.

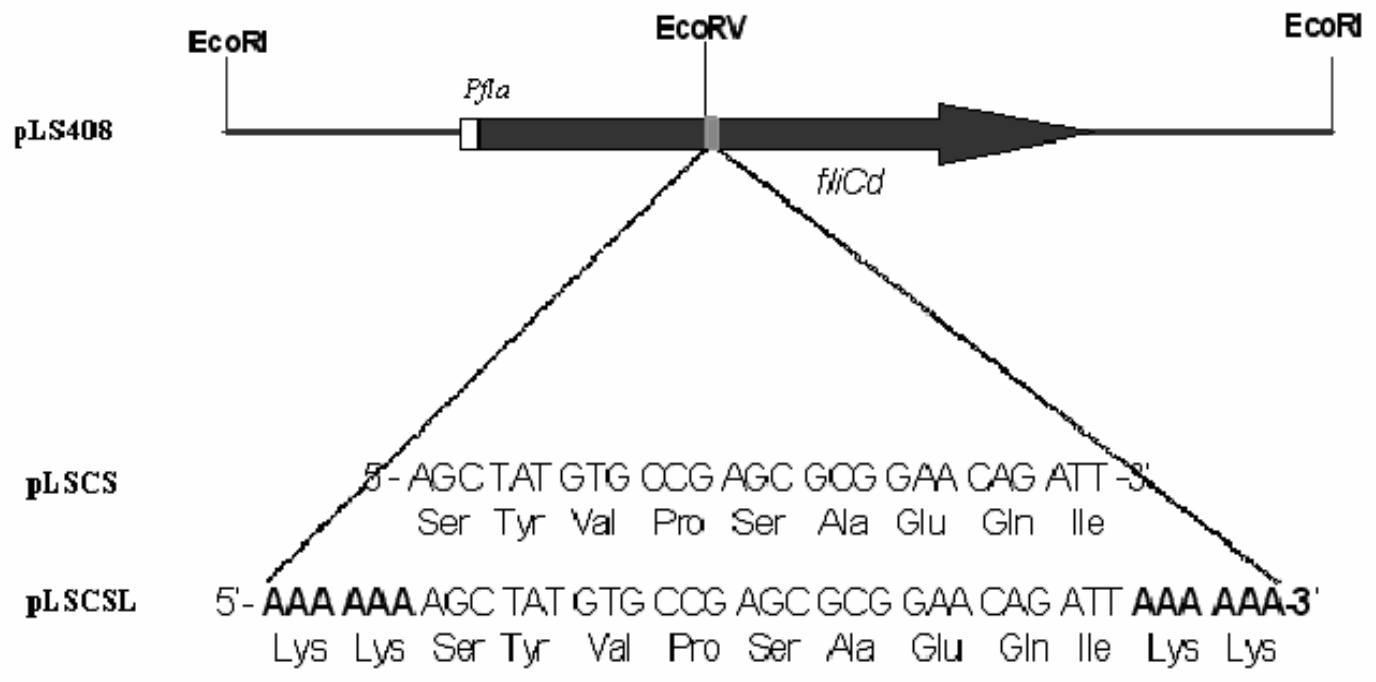

Figura 6: Representação esquemática da localização do epitopo CS no gene da flagelina FliCd. O plasmídeo pLS408 contêm o gene $f l i C d$, que codifica para a flagelina FliCd de $S$. Muenchen. A inserção de cada um dos oligonucleotídeos especificando o epitopo CS, ladeado (pLSCSL) ou não (pLSCS) por resíduos de lisinas, foi feita no sítio único de EcoRV após auto-anelamento de cada par de oligonucleotídeos, como descrito nos M\& M. 
4.3. Caracterização das linhagens vacinais de Salmonella quanto à expressão de flagelinas híbridas transportando epitopo CS de $P$. yoelli

A expressão das flagelinas híbridas por linhagens de $S$. Dublin foi feita inicialmente por ensaios de mobilidade em meio semi-sólido. As linhagens foram crescidas em meio contendo $0,35 \%$ de ágar e após $30 \mathrm{~h}$ de crescimento a $37^{\circ} \mathrm{C}$ a linhagem LDV500 apresentou mobilidade enquanto a linhagem LDV501 mostrou-se imóvel, quando comparadas com a linhagem parental SL5930 (Tabelas 1 e 3). A ausência de mobilidade da linhagem LDV501 despertou dúvidas sobre a montagem do flagelo híbrido na superfície da célula bacteriana. No entanto, dados da literatura indicam que a inserção de resíduos de aminoácidos na flagelina podem ocasionar perda da mobilidade flagelar, porém, sem interferir na expressão do flagelo ou em suas propriedades adjuvantes (VERMA et al., 1995). Para confirmarmos a montagem do flagelo, as frações correspondentes ao filamento flagelar foram extraídas de culturas feitas com a linhagens de Salmonella e analisada por imunodetecção em membrana de nitrocelulose utilizando anticorpo anti-FliCd (Figura 7B). Os resultados indicam que a ausência de mobilidade da linhagem LDV501 não impede a montagem do flagelo na superfície bacteriana. Os resultados mostram que o epitopo $\mathrm{T} \mathrm{CD}^{+}$restrito $\mathrm{CS}_{280-288}$ ladeado ou não por resíduos de lisina foi inserido na região hipervariável do gene que codifica para a flagelina FliC $d$ e que as linhagens LDV500 e LDV501 são capazes de expressar as flagelinas híbridas na superfície bacteriana na forma de filamento flagelar.

Tabela 3- Mobilidade das diferentes linhagens testadas em meio semi-sólido.

\begin{tabular}{l|c|c|c}
\hline \multirow{2}{*}{ Linhagens } & \multicolumn{2}{|c|}{ Flagelina Expressa } & Mobilidade* \\
\cline { 2 - 4 } & Cromossomal & Plasmidial & \\
\hline SL5928 & Não & Não & - \\
\hline SL5930 & Não & Sim & +++ \\
\hline LDV500 & Não & Sim & ++ \\
\hline LDV501 & Não & Sim & - \\
\hline
\end{tabular}

* Diâmetro do halo de crescimento medido em 30 horas de incubação a $37^{\circ} \mathrm{C}$

$0 \mathrm{~cm}$ a $0,5 \mathrm{~cm} \quad-$

$0,6 \mathrm{~cm}$ a $3,0 \mathrm{~cm}+$

$3,1 \mathrm{~cm}$ a $7,0 \mathrm{~cm}++$

acima de $7,1 \mathrm{~cm}+++$ 
(A)

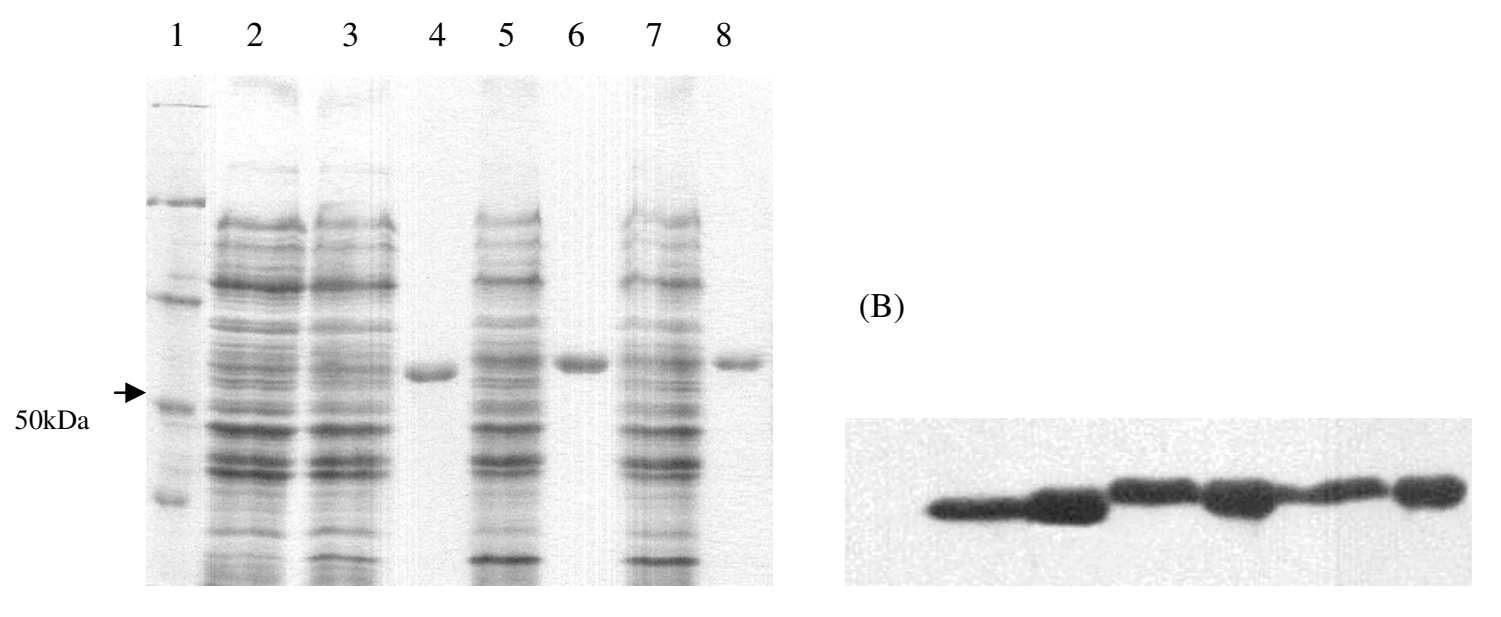

Figura 7: Expressão in vitro das flagelinas híbridas por linhagens vacinais de $S$. Dublin. (A) Gel de poliacrilamida $12,5 \%$ (SDS-PAGE) ou (B) imunodetecção em filtro de nitrocelulose com soro anti-FliCd. 1Padrão de massa molecular, 2- Extrato total da linhagem SL5928, 3- Extrato total da linhagem SL5930, 4Flagelina purificada da linhagem SL5930 (FliCd), 5- Extrato total da linhagem LDV500, 6- Flagelina purificada da linhagem LDV500 (FliCd-CS), 7 -Extrato total da linhagem LDV501, 8- Flagelina purificada da linhagem LDV501 (FliCd-CSL).

\subsection{Avaliação do potencial adjuvante da flagelina FliCd de $S$. Dublin na ativação de resposta imune celular específica para o epitopo CS por diferentes vias}

Flagelinas híbridas contendo o epitopo CS, ladeado ou não por resíduos de lisinas, foram obtidas a partir das linhagens LDV500 e LDV501 e, juntamente com o peptídeo pCS co-administrado com $\mathrm{FliC} d$, utilizadas em formulações vacinais administradas pelas vias s.c. ou i.n. a camundongos da linhagem BALB/c. A administração de formulações vacinais baseadas em flagelinas por via s.c. mostrou que as diferentes formulações empregadas foram capazes de ativar o mesmo número de $\mathrm{T}$ específicas ao epitopo pCS, com resultados comparáveis ao encontrado com a formulação vacinal que empregou peptídeo pCS e o 
adjuvante CFA (Figura 8). Os resultados mostram que a flagelina FliCd fusionada ou não ao antígeno de interesse foi capaz de promover ativação de respostas celulares específicas ao antígeno da malária.

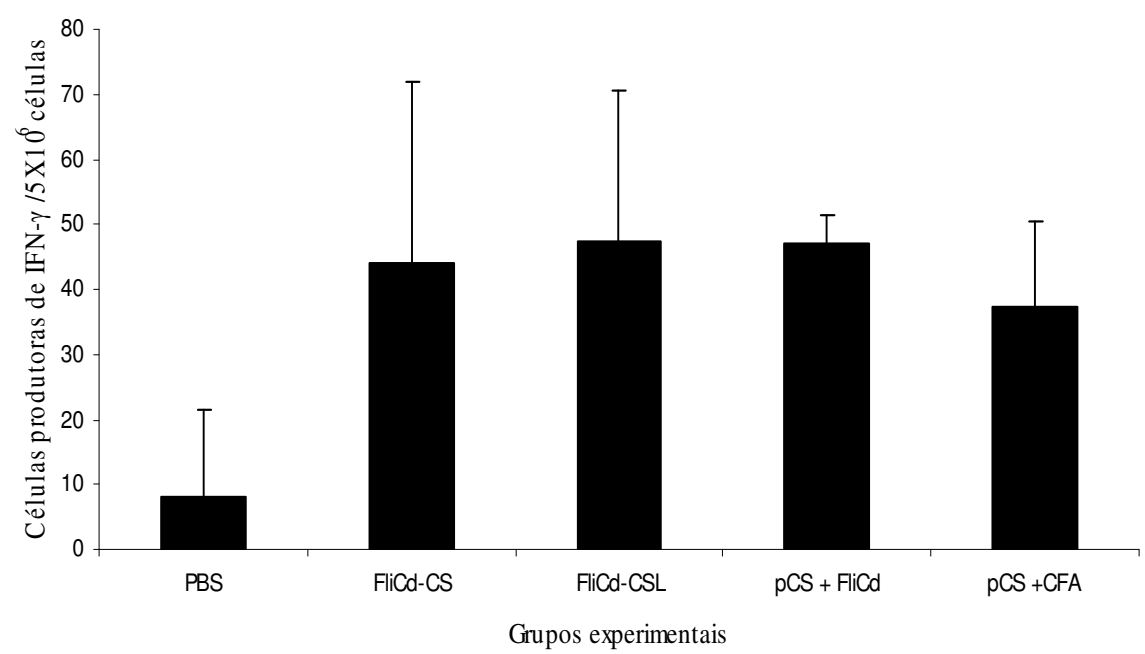

Figura 8: Efeito adjuvante da flagelina FliCd para o peptídeo pCS de $P$. yoelli. Camundongos BALB/c foram imunizados pela via s.c. com duas doses de Tampão salina fosfato (PBS), flagelina purificada da linhagem LDV500 (FliCd-CS), flagelina purificada da linhagem LDV501 (FliCd-CSL), o peptídeo pCS co-administrado com FliCd (pCS + FliCd) ou o peptídeo CS emulsificado com o adjuvante CFA (pCS + CFA). A resposta celular foi analisada por ELISPOT de células totais derivadas do baço dos animais. Os resultados referem-se ao número de células produtoras de IFN- $\gamma$ após estimulação in vitro com peptídeo $\mathrm{CS}_{280-288}$. Os dados apresentados referem-se à média de três experimentos independentes, realizados em duplicata, com grupos compostos de 3-4 animais.

A administração pela via i.n. de flagelinas híbridas com o epitopo pCS, ladeadas ou não por resíduos de lisina, não foi capaz de estimular células T específicas (Figura 9). No entanto, quando o peptídeo de interesse foi misturado com a flagelina nativa, a ativação de células $\mathrm{T}$ específicas foi superior aquela encontrada no grupo que recebeu a mesma quantidade de peptídeo pCS administrado com o adjuvante CFA. Os resultados mostram que flagelinas híbridas quando administradas pela via nasal, apresentam potencial adjuvante inferior à formulação vacinal na qual o antígeno heterólogo foi co-administrado com a flagelina. 


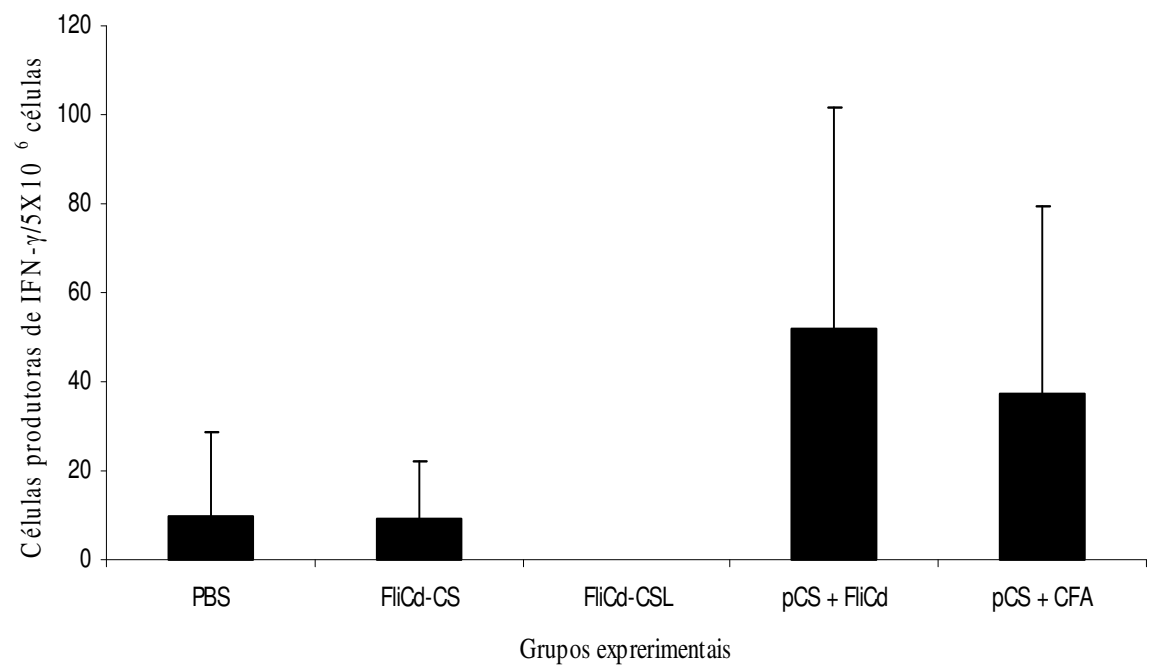

Figura 9: Efeito adjuvante da flagelina FliCd para o peptídeo pCS de P. yoelli. Camundongos BALB/c imunizados pela via i.n. receberam duas doses com Tampão salina fosfato (PBS), flagelina purificada da linhagem LDV500 (FliCd-CS), flagelina purificada da linhagem LDV501 (FliCd-CSL), peptídeo pCS coadministrado com FliCd (pCS + FliCd). Um grupo de animais imunizado com duas doses do peptídeo pCS emulsificado com o adjuvante CFA (CS + CFA), administrado por via s.c., foi utilizado como controle positivo. Sete dias após a imunização as respostas celulares foram analisadas por ELISPOT com células totais de baço . Os resultados referem-se ao número de células produtoras de IFN- $\gamma$ após estimulação in vitro com peptídeo $\mathrm{CS}_{280-288}$. Os dados apresentados referem-se à média de 3-4 animais por grupo em ensaios realizados em duplicata.

Avaliamos a funcionalidade das células $\mathrm{T} \mathrm{CD} 8^{+}$pCS-específicas ativadas pelas formulações vacinais em ensaios de citotoxicidade in vivo com camundongos BALB/c. Após a imunização, todos os animais receberam $2 \times 10^{7}$ células marcadas com CFSE e com o peptídeo pCS pela via i.v. Após 24 h os animais foram submetidos à eutanásia, as células marcadas foram recuperadas dos baços e contadas com auxílio de um citômetro de fluxo. Os resultados apresentados na figura 10 revelaram que as flagelinas híbridas não estimularam de forma significativa respostas citotóxicas específicas frente a células marcadas com o peptídeo pCS. Por outro lado, a co-administração de FliCd e pCS resultou em indução de resposta citotóxica específica, superior à resposta obtida em animais imunizados com o adjuvante CFA. Os resultados demonstram que a formulação vacinal baseada na co-administração do peptídeo pCS e FliCd foi capaz de ativar linfócitos T citotóxicos funcionais específicos para o epitopo da proteína CS de $P$. yoelli. 


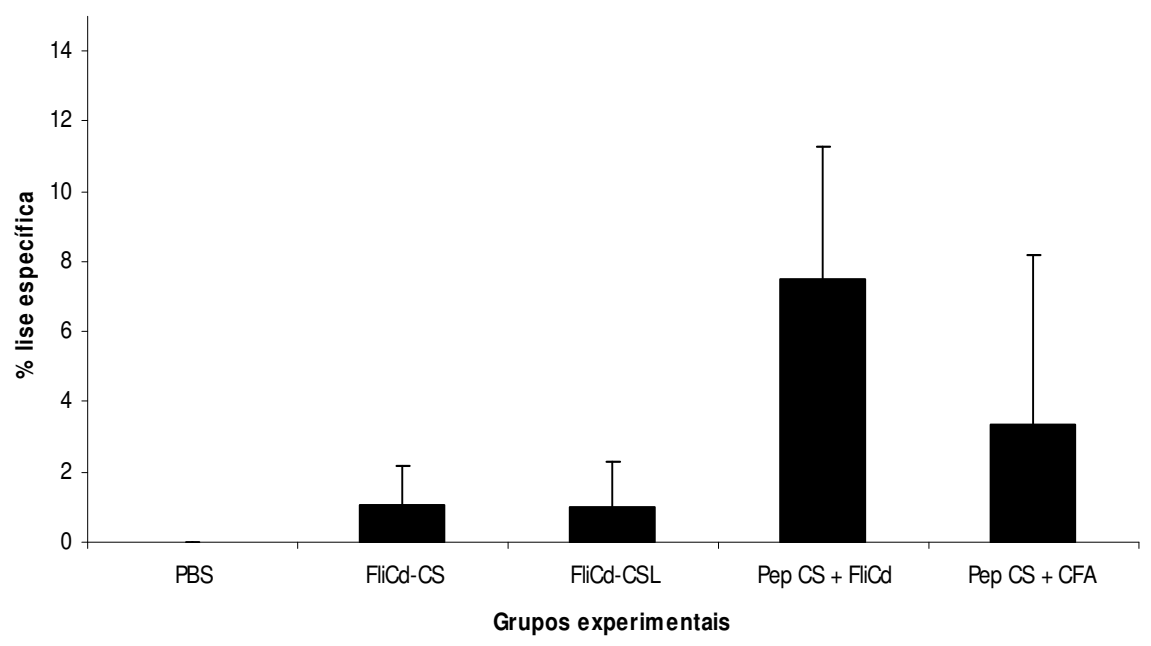

Figura 10: Avaliação da citotoxicidade in vivo gerada em camundongos imunizados com o peptídeo CS. Camundongos BALB/c foram imunizados por via s.c. com duas doses de tampão salina fosfato (PBS), flagelina purificada da linhagem LDV500 (FliCd-CS), flagelina purificada da linhagem LDV501 (FliCd-CSL), peptídeo pCS co-administrado à flagelina FliCd (pCS + FliCd) e peptídeo pCS emulsificado com o adjuvante CFA (pCS + CFA). Após a imunização, $2 \times 10^{7}$ células-alvo foram tranferidas para todos os camundongos e após $24 \mathrm{~h}$ recuperadas e contadas em citômetro de fluxo. Os resultados representam o percentual de células mortas em $2 \times 10^{7}$ células-alvo. Os resultados correspondem à média de quatro animais por grupo. Os resultados referem-se à morte celular mediada por células $\mathrm{T} \mathrm{CD}^{+}$citotóxicas específicas para o peptídeo pCS. Os resultados correspondem à média de 4 animais por grupo.

\subsection{Salmonella atenuada como veículo vacinal para antígeno da malária}

Como última etapa do trabalho, avaliamos o potencial adjuvante de linhagens recombinantes de Salmonella para a indução de respostas imunológicas celulares. Os plasmídeos pLSCS e pLSCSL, codificando para as flagelinas híbridas, foram introduzidos na linhagem atenuada de $S$. Dublin SL5928. Desta forma, foram obtidas as linhagens LDV500 e LDV501 capazes de expressar as flagelinas híbridas contendo o epitopo CS ladeado ou não por resíduos de lisinas, respectivamente. Grupos formados por 6-7 camundongos da linhagem $\mathrm{BALB} / \mathrm{c}$ foram imunizados com três doses de cada uma das linhagens por via oral. Após a imunização metade dos animais foram submetidos à avaliação da ativação de respostas 
celulares medidas pela indução de células produtoras de IFN- $\gamma$ específicas para o peptídeo pCS, em células totais de baço. O restante dos animais imunizados com as linhagens de $S$. Dublin LDV500 e LDV501 receberam um reforço com peptídeo pCS (25 $\mu \mathrm{g})$ co-administrado com o adjuvante IFA pela via sub-cutânea. Após o reforço, os animais foram submetidos à avaliação de respostas celulares por ELISPOT. Os resultados apresentados na figura 11 mostram que após três doses de Salmonella recombinante por via oral não foi possível detectar células $\mathrm{T}$ produtoras de IFN- $\gamma$ específicas para o epitopo pCS. Porém, animais imunizados com a linhagem LDV 501, mas não aqueles imunizados com a linhagem LDV500, desenvolveram respostas CS-específicas após receber reforço administrado por via parenteral.

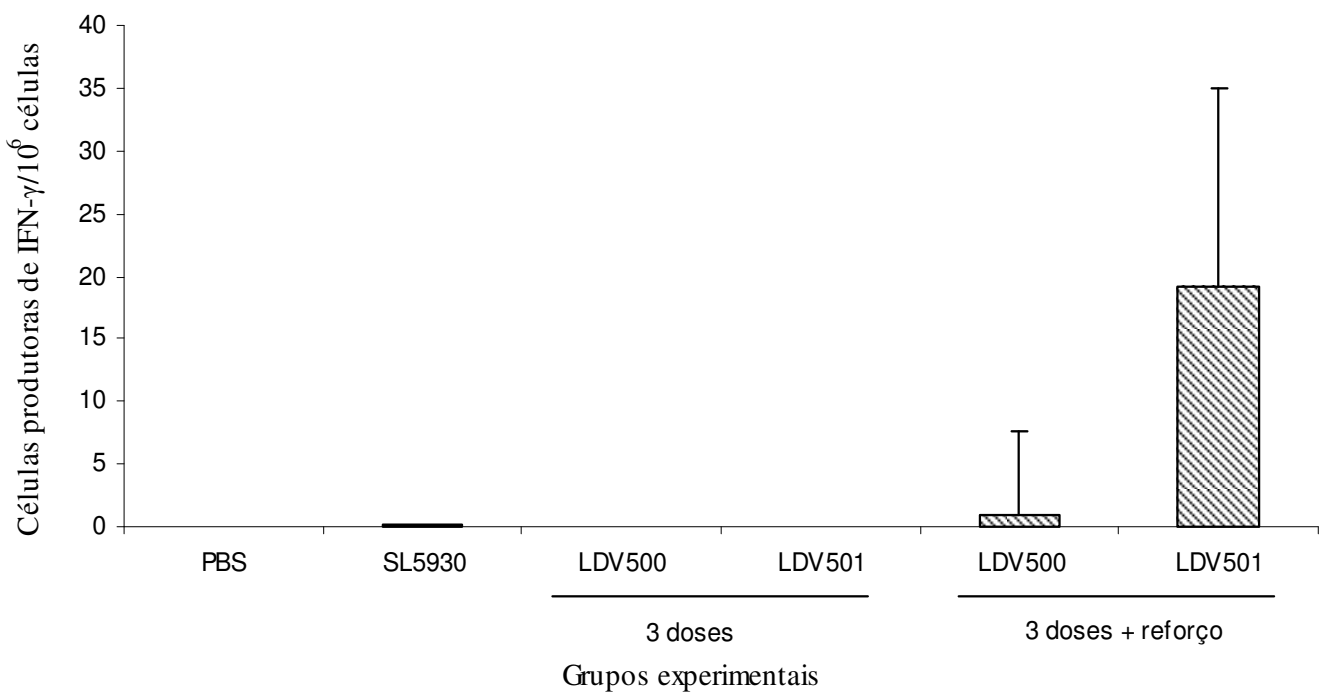

Figura 11: Indução de resposta celular específica para o peptídeo pCS de $P$. yoelli após imunização com linhagens vacinais de $S$. Dublin. Camundongos BALB/c receberam três doses v.o. de tampão salina fosfato (PBS), S. Dublin (SL5930), S. Dublin expressando FliCd fusionada ao epitopo CS (LDV500), S. Dublin expressando FliC $d$ fusionada ao epitopo CS ladeado por resíduos de lisina (LDV501). Animais imunizados com Salmonella receberam $10^{10}$ células/dose. Após a imunização, as respostas celulares induzidas foram analisadas por ELISPOT. Metade dos animais imunizados com as linhagens LDV500 e LDV501 receberam reforço parenteral com o peptídeo pCS emulsificado com o adjuvante IFA por via s.c.. Os resultados referem-se ao número de células produtoras de IFN- $\gamma$ após estimulação in vitro com peptídeo pCS e representam a média de dois experimentos independentes, realizados em duplicata com grupos compostos de 6-8 animais. 


\section{5- Discussão}

Vacinas representam um importante instrumento para a promoção e a manutenção da saúde pública mundial, entretanto, o controle de certas doenças persistentes, como infecções crônicas e cânceres, ainda permanece como um grande desafio para a pesquisa de novas estratégias vacinais. Apesar do acúmulo de conhecimentos sobre o sistema imunológico, interação patógeno-hospedeiro e mapeamento de antígenos protetores, essas informações ainda não foram traduzidas em vacinas eficazes, em parte devido a grande dificuldade de estabelecer uma ampla e duradoura proteção imunológica mediada por células, principalmente células $\mathrm{T} \mathrm{CD}^{+}$, imprescindíveis na eliminação de patógenos intracelulares ou células transformadas.

A descoberta da importância da imunidade inata para o desenvolvimento da resposta imune adaptativa (mediada por linfócitos $\mathrm{B}$, linfócitos $\mathrm{T} \mathrm{CD}^{+}$e $\mathrm{T} \mathrm{CD}^{+}$) revolucionou a forma como compreendemos o funcionamento das vacinas frente ao sistema imunológico de mamíferos. Hoje é amplamente aceito que a imunidade inata pode ser ativada por estimulação de receptores TLR e que esta estimulação pode levar a uma forte resposta imune adaptativa específica.

O potencial adjuvante de flagelinas de Salmonella sp., agonista do TLR 5, foi evidenciado em vários estudos que demonstraram que esta molécula foi capaz de aumentar respostas imunológicas celulares e humorais (RANVIDRAN et al., 2005; HONKO et al., 2006; CUADROS, et al., 2004; PINO et al., 2005; MCSORLEY et al., 2000; MCSORLEY et al., 2002; HONKO AND MIZEL, 2005). Suas características imunoestimuladoras sugerem ainda potencial adjuvante para células $\mathrm{T} \mathrm{CD}^{+}$, embora esse seja um aspecto pouco explorado. A demonstração de que flagelinas derivadas de salmonelas podem promover eficiente ativação de células $\mathrm{T} \mathrm{CD}^{+}$abre perspectivas para o estudo no controle de infecções crônicas, uma vez que poderão ser valiosas ferramentas para a composição de vacinas terapêuticas.

$\mathrm{Na}$ primeira parte deste trabalho buscamos diferenças nas propriedades imunestimuladoras de três tipos de flagelinas: FliCd, produzida por $S$. Müenchen e FliCi e FljB, produzidas por $S$. Typhimurium, na ativação de respostas imunológicas mediadas por células $\mathrm{T} \mathrm{CD} 8^{+}$específicas para o antígeno modelo ovalbumina. Na segunda parte do trabalho, após demonstrarmos uma ação diferencial da flagelina FliCd na estimulação de células $\mathrm{T}$ $\mathrm{CD}^{+}$, avaliamos a ação desse adjuvante frente a um peptídeo sintético correspondente ao 
epitopo MHC-I restrito da CS do P. yoelii. Finalmente, avaliamos a ativação de células T $\mathrm{CD}^{+}$por linhagens atenuadas de $S$. Dublin modificadas geneticamente para expressar o epítopo CS fusionado à flagelina $\mathrm{FliC} d$, após administração a camundongos pela via natural de infecção.

Utilizamos a ovalbumina como antígeno modelo e avaliamos a resposta para o epitopo MHC-I restrito OVA $257-264$. Os resultados encontrados sugerem que as três flagelinas estudadas atuam como adjuvantes para células $\mathrm{T} \mathrm{CD}^{+}$, embora o poder adjuvante observado tenha variado em função do tipo de flagelina utilizado, sendo os melhores resultados obtidos com a flagelina FliC $d$ quando comparada às flagelinas FljB e FliC $i$.

Embora alguns trabalhos tenham utilizado flagelina para ativação de respostas celulares, até o momento, não foi demonstrado se os diferentes tipos de flagelinas são capazes de promover graus comparáveis de adjuvanticidade para um mesmo antígeno. Ben-Yedidia (1999), Cuadros (2004), Sfondrini (2006) e Huleatt (2006), entre outros, utilizaram flagelinas como adjuvante para células $\mathrm{B}, \mathrm{T} \mathrm{CD}^{+}$e $\mathrm{T} \mathrm{CD}^{+}$, porém empregaram diferentes flagelinas de salmonelas ou mesmo de outras bactérias (LEE et al., 2006) para estimular respostas celulares para antígenos não relacionados.

As várias espécies de Salmonella produzem diferentes flagelinas (FljB, FliCd, FliCi), mas que se assemelham por conter aminoácidos $\mathrm{N}$ - e C- terminais conservados e uma região central hipervariável. As regiões conservadas das flagelinas são extremamente importantes para suas propriedades imunoestimuladoras, uma vez que interagem com o TLR 5 (NEWTON et al., 1989; YONEKURA et al., 2003; RAMOS et al., 2004; MURTHY et al., 2004; FLYNN et al., 1990; WEI et al., 1985, SMITH et al., 2003). Apesar das regiões ligadoras de TLR 5 apresentarem alto grau de conservação entre espécies, modificações por mutações pontuais de aminoácidos poderiam estabelecer diferenças na afinidade de ligação ao receptor e, consequientemente, graus diferenciados de ativação de células do sistema imunológico, ocasionando as diferenças encontradas (SMITH et al., 2003). Por outro lado, a região central da flagelina, também conhecida como região hipervariável, por conter apenas $30 \%$ de homologia de aminoácidos entre as espécies, é uma região rica em epítopos B mas também possui alguns epítopos T CD4 ${ }^{+}$(BERGMAN et al., 2005). Uma vez que epítopos T CD4 ${ }^{+}$são responsáveis pela ativação de células $\mathrm{T}$ auxiliares (Th), cuja função é ajudar na resposta de células B (sub-população Th2) ou de células $\mathrm{T} \mathrm{CD}^{+}$(sub-população Th1), diferenças qualitativas e quantitativas na composição de epítopos $\mathrm{T} \mathrm{CD}^{+}$, presentes na região hipervariável, poderiam ser as responsáveis pelas variações observadas nos tipos de 
flagelinas testados em relação aos efeitos adjuvantes frente a células T CD8 ${ }^{+}$.

Os resultados encontrados no presente trabalho complementam os apresentados pelo grupo de Huleatt (2006) que empregou duas formulações utilizando a flagelina FljB como adjuvante. Uma formulação era constituída de OVA fusionada geneticamente à flagelina enquanto a outra, utilizava OVA co-administrada à flagelina, ambas aplicadas por via parenteral (HULEATT et al., 2006). Os autores não encontraram anticorpos OVA-específicos em resposta à formulação vacinal que empregou OVA co-administrada à flagelina FljB. Como sugerido pelos autores, esse resultado indica que a ligação física do antígeno representaria um pré-requisito para o efeito adjuvante da flagelina FljB para a indução de anticorpos específicos. Embora não tenhamos explorado as propriedades adjuvantes das flagelinas de Salmonella em relação à produção de anticorpos específicos, dados não apresentados confirmam que a co-administração de diferentes flagelinas à OVA não aumentou de forma significativa a produção de anticorpos específicos. No entanto, nossos dados demonstram que a fusão genética do antígeno às flagelinas de Salmonella não é um pré-requisito para o efeito adjuvante frente a células $\mathrm{T}$, como observado com as flagelinas FliC $d$ e FliC $i$. Por outro lado, os resultados também sugerem que o potencial adjuvante da flagelina pode estar na dependência de outros fatores, como por exemplo o tipo empregado e não apenas a forma de administração, uma vez que a flagelina FljB não promoveu eficiente ativação de respostas celulares para o antígeno em questão estando na mesma apresentação.

A freqüência de células $\mathrm{T} \mathrm{CD}^{+}$antígeno específica é geralmente baixa, sendo, muitas vezes necessário a aplicação de metodologias mais adequadas para quantificá-las. Neste sentido, purificamos células $\mathrm{T} \mathrm{CD}^{+}$do baço de animais imunizados com OVA e com as flagelinas já citadas. O ELISPOT realizado a partir de células T $\mathrm{CD} 8^{+}$purificadas permitiu uma melhor visualização da ativação dessa população celular, uma vez que a freqüência de células específicas para o peptídeo $\mathrm{OVA}_{254-267}$ foi aumentada, e conseqüentemente, propiciou um aumento do número de células produtoras de IFN- $\gamma$ detectadas. Apenas no grupo de animais que recebeu flagelina $\mathrm{FliC} d$ com OVA não foi visualizado aumento na freqüência de células $\mathrm{T} \mathrm{CD}^{+}$produtoras de IFN- $\gamma$. Por outro lado, a resposta inicialmente vista para o grupo imunizado com a flagelina FljB e OVA foi aumentada porém, o aumento no número de células encontrado para a flagelina FljB não foi revelado em nem no ensaio ELISPOT nem no ensaio de citotoxicidade in vivo, de modo que será necessário a repetição do experimento para confirmação.

Além disto, a purificação de células $\mathrm{T} \mathrm{CD}^{+}$confirmou que a ativação inicialmente 
vista no ELISPOT foi devido à estimulação apenas de linfócitos $\mathrm{T} C D 8^{+}$e não outros tipos celulares capazes de produzir IFN- $\gamma$. Embora células totais derivadas do baço de animais imunizados tenham sido estimuladas in vitro com o peptídeo $\mathrm{OVA}_{254-267}$, específico para MHC-I, em certas ocasiões, a apresentação cruzada pode ocorrer. Apresentação cruzada ocorre quando um peptídeo, normalmente apresentado por uma via, passa a ser apresentado por outra via de apresentação de epitopos por moléculas de MHC. Neste caso o peptídeo $\mathrm{OVA}_{254-267}$, normalmente apresentado pela via MHC classe I para células T CD8 ${ }^{+}$, poderia ser apresentado pela via MHC classe II para células $\mathrm{T} \mathrm{CD} 4^{+}$, gerando resultados falso-positivos. Em adição, o ELISPOT de células $\mathrm{T} \mathrm{CD}^{+}$purificadas permitiu demonstrar com clareza o efeito adjuvante das diferentes flagelinas.

A avaliação do potencial adjuvante das flagelinas $\mathrm{FliC} d$, FliC $i$ e FljB para ativação de células $\mathrm{T}$ específicas para o epítopo $\mathrm{T} \mathrm{CD}^{+}$da OVA foi finalizada com o ensaio de citotoxicidade in vivo. Este ensaio demonstrou a atividade efetora de células T $\mathrm{CD}^{+}$ativadas pelas diferentes formulações vacinais. Linfócitos $\mathrm{T} \mathrm{CD}^{+}$sensibilizados são capazes de reconhecer antígenos em associação a moléculas MHC-I na superfície de células infectadas e promover a morte dessas células. Porém os mecanismos efetores envolvidos podem ser por uma via dependente de citocinas (principalmente IFN- $\gamma$ ), em que a célula infectada é estimulada a matar o patógeno, por uma via mediada por perforinas, em que a célula infectada é lisada, ou ainda por uma via mediada por FAS (membro 6 da superfamília TNF) em que as células-alvo são induzidas à auto-destruição (AIDOO e UDHAYAKUMAR, 2000; MORROT e ZAVALA, 2004). Todos esses mecanismos podem promover a atividade efetora de linfócitos $\mathrm{T} \mathrm{CD}^{+}$, porém, o ensaio de ELISPOT permitiu a detecção de apenas um desses mecanismos, aquele envolvido com a produção de IFN- $\gamma$. Os resultados encontrados mostram que as flagelinas FliC $d$ e FliC $i$ promoveram a ativação de células $\mathrm{T} C D 8^{+}$específicas para o peptídeo $\mathrm{OVA}_{254-267}$, e que esses linfócitos foram capazes de reconhecer células albergando o antígeno em sua superfície e promover efeitos citotóxicos. Os resultados sugerem que a flagelina $\mathrm{FljB}$ não foi eficiente na indução de efeitos citotóxicos na mesma proporção que as flagelinas FliC $d$ e FliC $i$.

A resposta citotóxica tem um grande significado, por representar um correlato de proteção, principalmente para antígenos de interesse clínico, sendo este o principal mecanismo responsável pelo controle de muitos vírus como o vírus influenza (TOPHAM et al, 1997), bactérias intracelulares como a L. monocytogenes (GREGORY e LIU, 2000) e parasitas como o Plasmodium sp. (RODRIGUES et al., 2003). 
Os ensaios realizados com a ovalbumina revelaram que a flagelina FliCd demonstrou o melhor efeito adjuvante para células $\mathrm{T} \mathrm{CD}^{+}$. De modo a avaliar os efeitos adjuvantes das flagelinas de Salmonella frente a um outro antígeno resolvemos examinar a habilidade da flagelina FliCd em potencializar respostas imunológicas T CD8-dependentes para o epítopo imunoprotetor MHC classe I-restrito presente na proteína de superfície CS de P. yoelli. A seqüência nucleotídica que representa o epítopo CS foi inserida no gene que codifica para a flagelina $\mathrm{FliC} d$, na região central hipervariável, ladeada ou não por resíduos de lisinas. Essa seqüência foi expressa como parte da flagelina FliCd nos filamentos flagelares expostas na superfície de linhagens atenuadas de Salmonella. Flagelinas híbridas purificadas a partir das linhagens recombinantes foram utilizadas para imunizações em camundongos BALB/c, bem como a flagelina FliCd co-adminstrada ao peptídeo pCS para avaliação do potencial adjuvante.

ELISPOT realizado a partir de células totais derivadas do baço de animais imunizados pela via s.c. com as flagelinas híbridas FliCd-CS ou FliCd-CSL, ou com flagelina nativa FliCd co-administrada ao peptídeo pCS, revelou que todas as formulações foram capazes de promover a ativação de células $\mathrm{T} \mathrm{CD}^{+} \mathrm{CS}$-específicas, em grau comparável à formulação que empregou peptídeo pCS e adjuvante CFA. É importante destacar a grande dificuldade em ativar respostas imunológicas para peptídeos sintéticos, uma vez que estes peptídeos são desprovidos de outros componentes imunoestimuladores, sendo considerados fracos imunógenos. Mesmo assim, a flagelina FliC $d$ foi capaz de ativar respostas celulares específicas para o peptídeo co-administrado. Por outro lado, é importante ressaltar que as flagelinas híbridas foram utilizadas na quantidade de $15 \mu \mathrm{g}$ por dose/animal e que o epitopo $\mathrm{T}$ $\mathrm{CD}^{+}$em questão representa apenas $0,27 \mu \mathrm{g}(1,8 \%)$ da massa utilizada, ou seja, a quantidade de antígeno CS utilizada nas formulações baseadas em flagelinas híbridas foi, de longe, menor que aquela utilizada na formulação não fusionada, onde o peptídeo pCS foi utilizado na quantidade de $25 \mu \mathrm{g}$ por dose/animal. Portanto, embora as diferentes formulações promovam graus comparáveis em número de células antígeno-específicas produtoras de IFN- $\gamma$, a fusão do antígeno ao adjuvante providenciou substancial aumento da imunogenicidade, uma vez que para quantidades inferiores de antígenos foram promovidas respostas similares. Os resultados encontrados no presente trabalho indicam que a fusão física do antígeno a flagelina não é essencial para sua adjuvanticidade mas potencializa a resposta imunológica para o antígeno heterólogo. Uma cinética deverá ser feita para verificação da quantidade mínima de antígeno co-administrado para o qual a flagelina pode mediar seus efeitos adjuvantes visando 
otimizar a formulação vacinal. Apesar de não conhecermos os mecanismos que favoreceram o maior efeito adjuvante de flagelinas híbridas frente à formulação co-administrada, a interação da flagelina híbrida com o TLR 5 e subseqüente favorecimento da endocitose pela APC poderia ser uma possível explicação. Ao ser ativada APC adquirem capacidade aumentada para processamento e apresentação de antígeno, além de aumentar a expressão de moléculas co-estimuladoras que são indispensáveis para a ativação de células T. Conseqüentemente, flagelinas híbridas providenciam, simultaneamente, dois estímulos para APC: a ativação do TLR 5 e o antígeno de interesse. Outra possibilidade reside no fato de que peptídeos são facilmente degradados por proteases do ambiente, sendo assim, o antígeno administrado no contexto da flagelina ficaria protegido à degradação por proteases teciduais, disponibilizando mais antígeno para o encontro com APC.

A observação inicial de Verma e colaboradores (1995) de que resíduos de lisina flanqueando um epitopo de interesse favoreceriam a excisão proteolítica do epitopo no interior de APC e o aumento de sua imunogenicidade, serviu de base para a construção de flagelinas híbridas contendo o epitopo heterólogo estudado. Os resultados revelaram que a inclusão de resíduos de lisina ladeando o epitopo CS inserido na flagelina não demonstrou vantagem mensurável em relação a imunogenicidade observada in vivo, uma vez que os resultados de ativação de linfócitos $\mathrm{T} \mathrm{CD}^{+}$específicos foram similares em animais imunizados com flagelinas FliCd-CS ou FliCd-CSL.

Outra via estudada foi a via nasal com a administração de flagelinas fusionadas ou não ao antígeno CS. Os resultados indicaram que apenas a formulação FliCd com pCS foi capaz de estimular a produção de IFN- $\gamma$ por células T específicas. Essa formulação vacinal mostrou ativação superior àquela encontrada nos animais imunizados com o peptídeo administrado com CFA pela via s.c. considerado controle positivo em nossos ensaios. Esses resultados confirmam observações anteriores que demonstraram o efeito adjuvante de flagelinas microbianas sobre respostas humorais e celulares específicas após a administração pela via nasal de antígenos e flagelinas (SFONDRINI et al., 2006).

O ensaio de citotoxicidade in vivo foi realizado para demonstrar a atividade efetora de células $\mathrm{T} \mathrm{CD}^{+}$ativadas pelas formulações vacinais baseadas no antígeno CS. Durante o estágio pré-eritrocítico da malária, hepatócitos infectados que expressam em sua superfície antígenos do parasita em associação a moléculas MHC-I são reconhecidos por linfócitos T $\mathrm{CD}^{+}$sensibilizados. Esse reconhecimento promove a ativação desses linfócitos e seus mecanismos efetores, resultando na morte da célula infectada. O papel de células $\mathrm{T} \mathrm{CD}^{+}$na 
proteção à malária é relevante apenas para os parasitas no estágio do fígado, pois os eritrócitos não expressam moléculas MHC-I, não podendo apresentar o peptídeo nem ser reconhecido por células efetoras. Apesar de bem estabelecido o papel de células $\mathrm{T} \mathrm{CD} 8^{+}$na imunidade protetora ao estágio pré-eritrocítico da malária, os mecanismos pelos quais estas células inibem o desenvolvimento do parasita ainda não foram completamente elucidados (AIDOO e UDHAYAKUMAR, 2000; MORROT e ZAVALA, 2004).

O papel de células $\mathrm{T} \mathrm{CD} 8^{+}$produtoras de IFN- $\gamma$ mediando a proteção a esporozoítas da malária foi demonstrado em vários estudos (SCHOFIEL et al., 1987; WEISS et al., 1988; ROMERO et al., 1989; WEISS et al., 1990; RODRIGUES et al., 1991; ASEGUINOLAZA et al., 2003; TSUJI e ZAVALA, 2003). Por outro lado, mecanismos dependentes de perforinas também foram documentados na imunidade mediada por linfócitos $\mathrm{T} C D 8^{+}$contra a malária em murinos e humanos (NUSSLER et al., 1993). Neste trabalho realizamos medidas de ativação celular baseados na detecção de células produtoras de IFN- $\gamma$ através do ELISPOT, porém, o ensaio de citotoxidade demonstra de forma direta a ação dos linfócitos ativados frente a células infectadas. Os resultados sugerem, que apesar das diferentes formulações mostrarem grau similar de ativação de células T produtoras de IFN- $\gamma$, quando administradas pela via subcutânea, o potencial para induzir morte de células alvo, foi superior no grupo de animais que receberam a formulação baseada em peptídeo pCS co-administrado à flagelina FliCd, possivelmente devido à ativação de outros mecanismos de citotoxicidade que não envolvem apenas a produção de IFN- $\gamma$. Apesar do ensaio de citotoxicidade representar a ação efetora desencadeada pelas formulações empregadas ele não garante a proteção contra o esporozoíta da malaria. Como não foi possível implantar o modelo experimental de desafio com formas esporozoítas de $P$. yoelli, permanece a dúvida sobre a real capacidade protetora dessas formulações vacinais.

Os resultados apresentados no presente trabalho sugerem o potencial vacinal de flagelinas de salmonelas para o desenvolvimento de vacinas terapêuticas uma vez que foram capazes de promover a ativação de células $\mathrm{T} C D 8^{+}$. No entanto, algumas vantagens de utilizar flagelinas fusionadas ou co-administradas devem ser consideradas. A fusão do antígeno à flagelina oferece, além de suas propriedades adjuvantes, a vantagem de servir como carregador molecular de antígenos heterólogos uma vez que epítopos ou mesmo sequiências inteiras de proteínas podem ser fusionados sem interferir em suas propriedades adjuvantes. Para vacinas baseadas em epítopos imunoprotetores, a fusão do epitopo à flagelina oferece a vantagem de protegê-lo contra degradação por proteases dos tecidos. Do ponto de vista 
biotecnológico, a fusão genética a flagelinas oferece vantagens nas etapas de produção e purificação do antígeno. A proteína híbrida pode ser produzida por bactérias em larga escala pela utilização de biorreatores e as etapas de purificação são destinadas a uma única proteína, mas que encerra propriedades de adjuvante e de antígeno. Por outro lado, os resultados apresentados neste trabalho sugerem que a ligação física do antígeno não é um fator imprescindível para o efeito adjuvante da flagelina. A abordagem onde a flagelina foi coadministrada ao antígeno demonstrou potencial adjuvante para ativação de células $\mathrm{T}$ quando administrada pelas vias subcutânea e de mucosa. A utilização de flagelinas não fusionadas oferece a vantagem de se dispor de um adjuvante universal que pode ser utilizado para diferentes antígenos peptídicos ou protéicos sem a necessidade de etapas de clonagem, geralmente laboriosas. De fato, diferentes pesquisadores demonstraram bons resultados com o emprego de flagelinas co-administradas a diversos antígenos, realçando a possibilidade de usá-la em co-administração (APPLEQUIST et al., 2005; LEE et al, 2006; McSORLEY, 2002; HONKO et al, 2006; DIDERLAURENT et al, 2004).

Veículos vacinais vivos têm sido utilizados por diferentes grupos para induzir em camundongos respostas de células $\mathrm{T} \mathrm{CD} 8^{+}$específicas para o epitopo da CS. Neste trabalho utilizamos linhagens atenuadas de $S$. Dublin expressando flagelinas híbridas (LDV 500 e LDV 501) para ativação de células $\mathrm{T} \mathrm{CD} 8^{+} \mathrm{CS}$-específicas em uma tentativa de aumentar as repostas encontradas com a utilização de proteínas purificadas. A utilização de salmonelas como veículo vacinal oferece várias vantagens, dentre elas, a estimulação de ampla resposta imunológica em seus hospedeiros, incluindo respostas celulares e a possibilidade de administração por via oral, uma via menos invasiva que dispensa o uso de seringas e pessoal treinado (SIEBERS e FINLAY, 1996; MASTROENI et al., 2000).

Nossos resultados revelaram que a administração do antígeno CS no contexto de uma linhagem vacinal de Salmonella, administrada por via oral, não foi capaz de ativar eficientemente linfócitos $\mathrm{T} C D 8^{+}$específicos ao epitopo CS. No entanto, após um reforço com o peptídeo pCS e o adjuvante IFA por via parentereal, detectamos células T produtoras de IFN- $\gamma$ específicas para o epitopo CS mas apenas nos animais que receberam a linhagem LDV 501. Esses resultados sugerem que, apesar da ausência de células produtoras de IFN- $\gamma$ no ELISPOT, a linhagem LDV 501 foi a única capaz de sensibilizar células T CD8 ${ }^{+}$específicas, uma vez que a apresentação do antígeno em outra formulação, como reforço, promoveu a expansão da população de linfócitos inicialmente sensibilizada. A observação de que apenas a linhagem LDV501, que expressa o epítopo CS ladeado por lisinas, foi capaz de sensibilizar 
células T CD8 ${ }^{+}$CS-específicas sugere que a adição de lisinas foi importante para o efeito encontrado após imunização pela via oral mas não para formulações baseadas em proteínas purificadas e administradas por via parenteral. De fato, resultados similares foram encontrados no trabalho de Verma e colaboradores (1995) após a administração de linhagens atenuadas de Salmonella expressando epitopos MHC-I e MHC-II restritos ladeado por lisinas. Salmonellas são patógenos intracelulares facultativos que costumam viver e se multiplicar no fagolisossoma e, nesse ambiente ácido, os filamentos de flagelinas são despolimerizados em monômeros susceptíveis a ação de enzimas lisossômicas, dentre elas a catepsina B que reconhece resíduos de lisinas como sítio de clivagem, provocando a excisão do epítopo CS. O extravasamento de peptídeos para o citosol e sua apresentação via MHC-I para células T $\mathrm{CD}^{+}$, têm sido um dos mecanismos propostos para a apresentação de antígenos exógenos por esta via.

Em estudos anteriores, linhagens atenuadas Salmonella expressando a proteína CS foram utilizadas como veículo vacinal pela via oral com o objetivo de induzir respostas celulares em camundongos (SADOFF et. al., 1988; AGGARWAL et al., 1990). Os resultados obtidos mostraram que a formulação empregada foi capaz de induzir resposta protetora contra desafio com esporozoítas de $P$. berghei e $P$. falciparum, e que a proteção foi mediada principalmente por CTL e parte por anticorpos direcionados contra a seqüência repetida da CS, sendo que a proteína CS também possui epítopos $\mathrm{T} \mathrm{CD}^{+}$que poderiam auxiliar na ativação de células $\mathrm{B}$ e $\mathrm{T} \mathrm{CD}^{+}$, potencializando o efeito da formulação. A participação desses epítopos foi demonstrada após a depleção in vivo da população $\mathrm{T}_{\mathrm{CD}}{ }^{+}$e permanência de proteção parcial contra o desafio. Em nosso modelo, utilizamos apenas um epítopo T $\mathrm{CD} 8^{+}$da proteína CS e, conseqüentemente, não contamos com a presença de epítopos $\mathrm{T} \mathrm{CD}^{+}$que poderiam auxiliar na resposta celular induzida. Provavelmente, esse fato explicaria os baixos valores de células $\mathrm{T} \mathrm{CD}^{+} \mathrm{CS}$-específicos encontrados e a necessidade de um reforço com peptídeo por outra via de administração para detectarmos respostas mensuráveis. A fraca ativação observada após a utilização de nossas linhagens vacinais não pode ser atribuída à segregação plasmidial e, conseqüentemente, à baixa expressão e entrega do antígeno heterólogo às células do sistema imune, uma vez que a quantidade de antígeno transportada pela bactéria no momento da imunização era suficiente para estimular as APC, conforme analisado em trabalhos anteriores do grupo (ALMEIDA et al, 1999). Outra suposição foi a ocorrência de tolerância após a imunização por via oral, mas esta hipótese foi descartada quando os resultados mostraram a ativação de células T específicas para o peptídeo CS $2_{80-288}$ 
em camundongos que receberam um reforço com peptídeo CS e IFA administrados por via s.c.

Outra questão levantada foi a indução de morte celular programada (apoptose) por um mecanismo dependente da ativação de caspase-I em células dendríticas e macrófagos após infecção com Salmonella, como descrito anteriormente (VELDEN et al., 2003). Células dendríticas exercem um importante papel no desenvolvimento da imunidade adquirida uma vez que possuem habilidades para capturar e degradar microrganismos invasores e apresentar peptídeos microbianos a linfócitos T. Desse modo, formam uma ligação importante entre a imunidade inata e adquirida, e, portanto, a morte dessas células implica em uma deficiência na estimulação de linfócitos T CD8 ${ }^{+}$. De fato, Velden e claboradores (2003), mostrou que a ausência de ativação de linfócitos $\mathrm{T}$ a células dendríticas infectadas por Salmonella seria decorrente não apenas da apoptose celular ou interferência na expressão das moléculas coestimuladoras, mas também revelou que a Salmonella causa um efeito inibidor dependente de contato direto com as células $\mathrm{T}$, impedindo-as de proliferar e produzir citocinas em resposta a estimulação.

O presente trabalho demonstrou que a flagelina FliCd derivada da $S$. Muenchen foi capaz de ativar células T $\mathrm{CD}^{+}$específicas para epitopos derivados das proteínas OVA e CS abrindo perspectivas para sua utilização em vacinas terapêuticas. Porém, considerando a complexidade do ciclo de vida do Plasmodium sp., apenas a resposta mediada por células T $\mathrm{CD}^{+}$dirigida para a CS não seria suficiente para o desenvolvimento racional de uma vacina contra malária. Muitos aspectos, relacionados a doença, tais como o ciclo de vida do parasita, multiplicidade de antígenos alvos e mecanismos efetores envolvidos na resposta imune protetora devem ser considerados na busca de uma estratégia vacinal profilática ou terapêutica efetiva. Diversos estudos demonstraram que imunidade protetora à malária pode ser induzida em animais e humanos por imunização com esporozoítas atenuados por radiação, indicando que uma vacina contra a malária pode ser construída baseada apenas no estágio préeritrocítico (KAPPE et al.,2004). Além disso, entre as várias estratégias de vacinação contra a malária propostas, a prevenção da entrada do parasita no hepatócito ou o bloqueio de seu desenvolvimento intracelular tem a vantagem singular de atuar antes dos sintomas da doença, associados ao estágio eritrocítico da infecção. Contudo, vacinas "pré-eritrocíticas" devem ser $100 \%$ efetivas porque um único esporozoíta sobrevivente ainda poderá causar uma infecção letal quando passar para a fase sanguínea. Neste caso, vários mecanismos efetores devem ser ativados para garantir a eliminação do parasita ainda na fase pré-eritrocítica como por exemplo, a produção de anticorpos contra a proteína CS neutralizaria a maioria dos 
esporozoítas enquanto eles ainda estivessem na corrente sanguínea e os poucos esporozoítas que sobrevivessem e invadissem as células hepáticas seriam eliminados por células $\mathrm{T} \mathrm{CD} 4^{+} \mathrm{e}$ $\mathrm{T} \mathrm{CD}^{+}$ou mecanismos dependentes de anticorpos. Porém, considerando que um schizonte sobrevivente pode produzir cerca de 30.000 merozoítas, é importante não só diminuir ao máximo a carga do parasita no fígado mas também incorporar à formulação vacinal um antígeno da fase eritrocítica, capaz de mediar a produção de anticorpos neutralizantes das formas merozoítas, e evitar a infecção de hemácias. Por fim, uma vacina contra a malária deve providenciar rápida e total eliminação do parasita antes de sua transformação dentro do hepatócito. Desta forma é possível que abordagens para o controle vacinal da malária venham empregar diferentes antígenos alvos e estratégias de ativação imunológica, reflexo da complexidade do parasita e sua relação com o hospedeiro mamífero.

\section{Conclusões e Perspectivas}

- Flagelinas derivadas de Salmonella sp. podem atuar como adjuvantes para ativação de células $\mathrm{T} \mathrm{CD}^{+}$específicas para um dado antígeno.

- O potencial adjuvante para ativação de células $\mathrm{T} \mathrm{CD8}^{+}$é dependente do tipo de flagelina utilizado, sendo que a flagelina FliCd produzida por $S$. Müenchen demonstrou efeito adjuvante superior ao da flagelina $\mathrm{FliC} i$ produzida por $S$. Typhimurium quando co-adminstradas a OVA. Enquanto a flagelina FljB produzida por $S$. Typhimurium não apresentou efeito adjuvante para ativação de células T $\mathrm{CD} 8^{+}$, quando co-administrada ao antígeno OVA.

- Flagelinas fusionadas geneticamente ao antígeno de interesse são capazes de promover ativação de células $\mathrm{T}$ antígeno-específicas quando administradas por via parenteral e oferecem a vantagem de funcionar, simultaneamente, como carregador molecular e imunoestimulador. 
- A ligação física do antígeno não é um fator limitante para o potencial adjuvante da flagelina FliCd, capaz de promover respostas celulares específicas para o antígeno coadministrado.

- A utilização de resíduos de lisinas flanqueando o epitopo $\mathrm{CS}_{280-288}$ não aumentou o efeito adjuvante frente ao peptídeo em camundongos imunizados pela via subcutânea ou nasal com flagelinas purificadas.

- Flagelina FliCd ativou mecanismos efetores responsáveis pela morte de células cobertas com peptídeos, como medido em ensaios de citotoxicidade in vivo.

- Linhagens atenuadas de $S$. Dublin carregando o epitopo ladeado por resíduos de lisinas em fusão à flagelina FliC $d$ foram capazes de sensibilizar células $\mathrm{T} C D 8^{+}$virgens após a administração de um reforço pela via parenteral.

- Os resultados obtidos abrem perspectivas promissoras para o estudo do potencial da flagelina FliCd de Salmonella como adjuvante vacinal em formulações com características terapêuticas, tanto na forma de proteína purificada co-administrada ou fusionada a antígenos como na forma de linhagens atenuadas vivas administradas pela via oral. 


\section{6- Referências}

AGGARWAL, A.; KUMAR, S.; JAFFE, R.; HONE, D.; GROSS, M. AND SADOFF, J. (1990). Oral Salmonella: Malaria Circunsporozoito Recombinants Induce Specific CD8+ Cytotoxic T Cells. The Journal of Experimental Medicine, 172:1083-1090.

AIDOO, M. AND UDHAYAKUMAR, V. (2000). Field Studies of Cytotoxic T Lymphocytes in Malaria Infection: Implications for Malaria Vaccine Development. Parasitology Today, v.16, n. 2 , p. 50-56.

AKIRA, S. AND TAKEDA, K. (2004). Toll-like receptor signaling. Nature reviews immunology, 4:499-511.

ALMEIDA, M.E.S ; NEWTON, S. M. C. ; FERREIRA, L. C. S. (1999). Antibody responses against flagellin in mice orally immunized with attenuated Salmonella vaccine strains. Archives of Microbiology, v. 172, p. 102-108.

APPLEQUIST, S.E.; ROLLMAN, E.; WAREING, M.D.; LIDÉN, M.; ROZELL, B.; HINKULA, J. AND LJUNGGREN, H.G. (2005). Activation of innate imunity , inflammation, and potentiation of DNA vaccinaton though mammalian expression of the TLR5 agonist flagellin. The Journal of Immunology , 3882-3891.

ASEGUINOLAZA, G.G.; NAKAYA, Y.; MOLANO, A.; DY, E.; ESTEBAN, M.; RODRIGUEZ, D.; RODRIGUEZ, J.R.; PALESE, P.; SASTRE, A.G. AND NUSSENZWEIG, R.S.(2003). Induction of Protective against Malaria by Priming-Boosting Immunization with Recombinant Cold-Adapted Influenza and Modified Vaccinia Ankara Viruses Expressing a CD8 ${ }^{+}$-T-Cell Epitope Derived from the Circumsporozoite Protein of Plasmodium yoelii. Journal of Virology, pp. 11859-11866.

AUTRAN, B.; CARCELAIN, G.; COMBADIERE, B.H.; DEBRE, P. (2004). Therapeutic Vaccines for Chronic Infections. Science. 305:205-208.

BARBER, D.L.; WHERRY, E.J. AND AHMED, R. (2003). Cutting Edge: Rapid In Vivo 
Killing by Memory CD8 T Cells1. The J. of Immunol., 171:27-31.

BERGMAN, .A.; CUMMINGS, L.A.; ALANIZ, R.A.; MAYEDA, L.; FELLNEROVA, I. AND COOKSON, B.T. (2005). CD4 ${ }^{+}$-T-CELL Responses Generated during Murine Salmonella enterica Serovar Typhimurium Infection are Directed towards Multipli Epitopes within the Natural FliC. Inf. And Immun., 73:7226-7235.

CHEN, D.H.; TIGELAAR, R.E. AND WEINBAUM F.I. (1977). Immunity to sporozoiteinduced malaria infection in mice. I. The effect of immunization of $\mathrm{T}$ and $\mathrm{B}$ cell deficient mice. Journal of Imunology, 118:1322

CHUNG, N.P.Y.; CHEN, Y.; CHAN, V.S.F.; TAM, P.H.K. AND LIN, C.L.S. (2004). Dendritic cells: sentinels against pathogens. Histology and Histopathology,19:317-324.

CUADROS, C.; LOPEZ-HERNANDEZ F.J.; DOMINGUEZ, A.L.; MCCELLAND, M. AND LUSTGARTEN, J. (2004). Flagellin Fusion Proteins as Adjuvants or Vaccines Induce Specific Immune Responses. Infection and Immunity, 72: 2810-2816.

CUNNINGHAM, A.F.; KHAN, M.; BALL, J.; TOELLNER, K.M.; SERRE, K.; ELODIE, M. AND MACLENNAN, C.M. (2004). Response to the soluble flagellar protein FliC are Th2, while those to FliC on Salmonella are Th1. Eur. Journal Immunology, 34:2986-2995.

DIDIERLAURENT, A.; FERRERO I.; OTTEN, L.A.; DUBOIS, B.; REINHARDT, M.; CARLSEN, H.; BLOMHOFF, R.; AKIRA, S.; KRAEHENBUHL, J.P. and SIRARD, J.C. (2004). Flagellin Promotes Myeloid Differentiation Factor 88-Dependent Development of Th2-Type Response. Journal Immunology, 172:11:6922-6930.

FLYNN, J.L.; WEISS, W.R.; NORRIS, K.A.; SEIFERT, H.S.; KUMAR, S. AND SO, M. (1990). Generation of a cytotoxic T-lymphocyte response using a Salmonella antigen-delivery system. Molecular Microbiology, 4, pp. 2111-2118. 
GIUDICE, G.D. (2003). Vaccination strategies An overview. Vaccine, 21:S2/83-S2/88

HONKO, A.N. AND MIZEL, S.B. (2005). Effects of Flagellin on Innate and Adaptative Immunity. Immunologic Research, 33/1: 83-101.

HONKO, A.N.; SRIRANGANATHAN, N.; LEES, C.J. AND MIZEL, S.B. (2006). Flagellin Is a Effective Adjuvant for Immunization against Lethal Respiratory Challenge with Yersinia Pestis. Infection and Immunity, 1113-1120

HULETT, J.W.; JACOBS, A.R.; DESAI, P.; KOPP, E.B.,; HUANG, Y.; SONG, L.; NAKAAR, V. AND POWELL, T.J. (2006). Vaccination with recombinant proteins incorporating Toll-like receptor ligands induces rapid cellular and humoral immunity. Vaccine. pp. 1-13.

JONES, T.R. AND HOFFMAN, S.L. (1994). Malaria Vaccine Development. Clinical Microbiology Reviews, 7:303-310.

KAISHO, T. AND AKIRA, S. (2002). Toll-like receptors as adjuvant receptors. Biochimic et Biophysica Acta, 1589:1-13.

KAPPE，S.H.I.; BUSCAGLIA， C.A. AND NUSSENZWEIG， V. (2004). Plasmodium Sporozoite Molecular Cell Biology. Annu. Rev. Cell Dev. Biol, 20:29-59.

KRIEG, A.M.(2007). Toll-free vaccines?. Nature Biotechnology, 25:3:303-305.

LEE, S.E.; KIM, S.Y.; JEONG, B.C.; KIM, Y.R.; BAE, S.J.; AHN, O.S.; LEE, J.J.; SONG, H.C.; KIM, J.M.; CHOY, H.E.; CHUNG, S.S.; KWEON, M.N. and RHEE, J.H. (2006). A bacterial flagellin, Vibrio vulnificus FlaB, Hás a strong Mucosal Adjuvant activity To Induce Protective Immunity. Infection and Immunity, 694-702.

LI, S.; RODRIGUES, M.; RODRIGUEZ, D.; RODRIGUEZ, J.R.; ESTEBAN, M.; PALESE, P.; NUSSENZWEIG, R.S. AND ZAVALA, F. (1993). Priming with recombinant influenza 
virus followed by administration of recombinant vaccinia virus induces CD8+ T-cellmediated protective immunity against malaria. Proc Natl Acad Sci USA, 90:5214-5218.

LUNA, M.G.; MARTINS, M.M.; NEWTON, S.M.C.; COSTA, S.O.P.; ALMEIDA, D.F. and FERREIRA, L.C.S. (1997). Cloning and expression of colonization factor antigen I (CFA/I) epitopes of enterotoxigenic Escherichia coli (ETEC) in Salmonella flagellin. Res. Microbiol., $148: 217-228$.

McSORLEY, S.J.; COOKSON, B.T. AND JENKINS, M.K. (2000). Characterization of CD4+ T Cell Responses During Natural Infection with Salmonella typhimurium. The Journal of Immunology, 986-993.

McSORLEY, S.J.; EHST, B.D.; YU, Y. AND GERWITZ, A.T. (2002). Bacteril Flagellin Is an Effective Adjuvante for CD4+ T Cells In Vivo. The Journal of Immunology, 169:39143919

MALIK, A.; EGAN, J.E.; HOUGHTEN, R.A.; SADOFF, J.C. AND HOFFMAN, S.L. (1991). Human cytotoxic $\mathrm{T}$ lymphocytes against the Plasmodium falciparum circumsporozoite protein. Proc Natl Acad Sci USA, 88:3300-3304.

MASSIS, L.M.; SBROGIO-ALMEIDA, M.E.; LAUAND, C.; BRAGA, C.J.M.; NEWTON, S.M.C.; KLEBBA, P.E. AND FERREIRA, L.C.S.. (2007). Antibody inducing properties of flagellin expressed by orally delivered attenuated Salmonella vaccine strains. Submetido à publicação.

MASTROENI, P., CHABALGOITY, J.A., DUNSTAN, S.J., MASKELL, D.J. AND DOUGAN, G. (2000). Salmonella: Immune Responses and Vaccines. The Veterinary Journal, 161, pp.132-164.

MINISTÉRIO DA SAÚDE 2003. Secretaria de Vigilância em Saúde, Programa Nacional de Prevenção e Controle da Malária, PNCM, Brasília, DF. 
MIZEL, S.B.; WEST, A.P. AND HANTGAN, R.R. (2003).Identification of a Sequence in Human Toll-like Receptor 5 Required for the Binding of Gram-negative Flagellin. The Journal of Biological Chemistry, 278:23624-23629.

MIYAHIRA, Y.; MURATA K.; RODRIGUES, D.; RODRIGUEZ, J.R.; ESTEBAN, M.; RODRIGUES, M.M. AND ZAVALA, F. Quantification of antigen Specific CD8 ${ }^{+}$Cells using an ELISPOT assay. (1994). Journal of Immunological Methodos, 181: 45-54.

MORROT, A. AND ZAVALA, F. (2004). Effector and memory CD8+ T cells as seen in immunity to malaria. Immunol Reviews, v. 201, p. 291-303.

MURTHY, K.G.K.; DEB, A.; GOONESEKERA, S. and SZABÓ, C. (2004). Identification of Conserved Domains in Salmonella muenchen Flagellin that are Essential for Its Ability to Activate TLR5 and to induce an Inflammatory Response in vitro. The Journal of Biological Chemistry, 279:5667-5675.

NEWTON, S.M.C.; JACOB, C.O. \& STOCKER, B.A.D. (1989). Immune Response to Cholera Toxin Epitope Inserted in Salmonella Flagellin. Science, 244:70-72

NEWTON, S.M.C. \& STOCKER, B.A.D. (1991a). Insertion of heterologous epitopes in Salmonella flagellin. Mem. Inst. Butantan, 53:1 :53-58.

NEWTON, S.M.C.; KOTB, C.M.; POIRIER, T.P.; STOCKER, B.A.D. AND BEACHEY, E.H. (1991b). Expression and Immunogenicity of a streptococcal M protein epitope inserted in Salmonella flagellin. Infection and Immunity, 59: 2158-2165.

NUSSENZWEIG, V. AND NUSSENZWEIG, R.S. (1986). Development of a sporozoite malaria vaccine. Am. J. Trop. Med. Hyg., 24:397.

NUSSENZWEIG, V. AND NUSSENZWEIG, R.S. (1989). Rationale for the development of an engineered sporozoite malaria vaccine. Adv. Immunology, 45:283-334.

O'HAGAN, D.T.; MACKICHAN, M.L. AND SINGH, M. (2001). Recent developments in 
adjuvants for vaccines against infectious diseases. Biom. Engen., 18 :69-85

PINO, O.; MARTIN, M. AND MICHALEK, S.M. (2005). Cellular Mechanisms of the Adjuvant Activity of the Flagellin Component FljB of Salmonella enterica Serovar Typhimurium To Potentiate Mucosal and Systemic Responses. Infection and Immunity, 73(10):6763-6770.

RAMOS H.C.; RUMBO, M. AND SIRARD, J.C. (2004). Bacterial Flagellins: mediators of pathogenicity and host immune responses in mucosa. Trends in Microbiology, 12: 509-517.

RAVINDRAN, R. AND MCSORLEY, S.J. (2005). Tracking the dynamics of T-cell activation in response to Salmonella infection. Imunology, 114: 450-458.

RODRIGUES, M.M; CORDEY A.S.; ARRAEZA, G.; CORRADIN, G.; ROMERO, P.; MARYANSKI, J.L.; NUSSENZWEIG, R.S. AND ZAVALA, F. (1991). CD8+ cytolytic T cell clones derived against the Plasmodium yoelii circumsporozoite protein protect against malaria. Int. Immunology, 3:579-585.

RODRIGUES, M.M; BOSCARDIN, S.B.; VASCONCELOS, J.R.; HIYANE, M.I.; SALY, G. AND SOARES, I.S. (2003) Importance of CD8 T cell-mediated immune response during intracellular parasitic infections and its implications for the development of effective vaccines. Anais da Acad. Brás. de Ciênc. 75(4):443-468.

ROMERO, P.; MARYANSKI， J.L.; CORRADING， G.; NUSSENZWEIG， R.S.; NUSSENZWEIG, V. AND ZAVALA, F. (1989). Cloned cytotoxic T cell recognize an epitope in the circunsporozoito protein and protect against malaria. Nature, 341:323-326.

ROMERO, B.O.; ASEGUINOLAZA, G.G.; HAFALLA, J.C.; TSUJI, M. AND NUSSENZWEIG, R.S. (2001). Complete, long-lasting protection against malaria of mice primed and boosted with two distinct viral vectors expressing the same plasmodial antigen. Proc Natl Acad Sci USA, 98: 11491-11496.

SADOFF, J.C.; BALLOU, W.R.; B ARON, L.S.; MAJARIAN, W.R.; BREY, R.N.; 
HOCKMEYER, W.T.; YOUNG, J.F.; CRYZ, S.J.; OU, J.; LOWELL, G.H. AND CHULAY, J.D. (1988). Oral Salmonella typhimurium Vaccine Expressing Circunsporozoito Protein Protects Against Malaria. Science, 240:336-338.

SCHOFIELD, L.; VILLAQUIRAN, J.; FERREIRA, A.; SCHELLEKENS, H.; NUSSENZWEIG, R. AND NUSSENZWEIG, V. (1987). Gamma interferon, CD8+ T cells and antibodies required for immunity to Malária sporozoites. Nature, 330:664-666.

SEDEGAH, M.; JONES, T.R.; KAUR, M.; HEDSTROM, R.; HOBART, P.; TINE, J.A. AND HOFFMAN, S.L. (1998). Boosting with recombinant vaccinia increases immunogenicity and protective efficacy of malaria DNA vaccine. Proc Natl Acad Sci USA, 95: 7648-7653.

SEDEGAH, M.; WEISS, W.; SACCI, J.B.J.; CHAROENVIT, Y.; HEDSTROM, R.; GOWDA, K.; MAJAM, V.F.; TINE, J.; KUMAR, S. AND HOBART, P.H.S..(2000). Improving protective immunity induced by DNA-based immunization: priming with antigen and GM-CSF-encoding plasmid DNA and boosting with antigen-expressing recombinant poxvirus. Journal of Immunol, 164: 5905-5912.

SFONDRINI, L.; ROSSINI, A., BESSUSO D. (2006).Antitumor Activity of the TLR-5 Ligand Flagellin in Mouse Models of Cancer. The J. of Immunology. 6624-6630.

SHIBAKI, A. AND KATZ, S.I. ( 2002). Induction of skewed Th1/Th2 T-cell differentiation via subcutaneous immunization with Freund's adjuvant. Experimental Dermatology, 11: $126-134$

SIEBERS, A. and FINLAY, B.B. (1996). M cells and the pathogenesis of mucosal and systemic infections. Trends in Microbiology, v. 4, p.22-29.

SMITH, K.D.; ANDERSEN-NISSEN, E.; HAYASHI, F.; STROBE, K.; BERGMAN, M.A.; BARRET, S.L.R.; COOKSON, B.T. AND ADEREM, A. (2003). Toll-like receptor 5 recognizes a conserved site on flagellin required for protofilament formation and bacterial 
motility. Nature Immunology, 4:1247-1253.

SOARES, I.S. AND RODRIGUES, M.M.. (1998). Malaria vaccine: roadblocks and possible solutions. Braz J Med Biol Res, 31: 317-332.

STEINMAN, R.M. AND POPE, M. (2002). Exploiting dendritic cells to improve vaccine efficacy. The Journal of Clinical Investigation, 109:12:1519-1526.

TAKEDA, K.; KAISHO, T. AND AKIRA, S. (2003). Toll-like receptors. Annu. Rev. Immunol, 21:335-376.

TSUJI, M. AND ZAVALA, F. (2003). T cells as mediators of protective immunity against liver stages of Plasmodium. Trends in Parasitology, 19:88-93.

VELDEN, A.W. VAN DER, VELASQUEZ, M. AND STARNBACH, M.N. (2003). Salmonella rapidly kill dendritic cells via a caspase-1-dependent mechanism. The Journal of Immunology, 6742-6748.

VERMA, N.K.; ZIEGLER, H.K.; WILSON, M.; KHAN, M.; SAFLEY, S.; STOCKER, B.A.D. AND SCHOOLNIK, G.K. (1995). Delivery of class I and class II MHC-restricted Tcell epitopes of listeriolysin of Listeria monocytogenes by attenuated Salmonella. Vaccine, $13: 142-150$.

WATERS, A.P.; MOTA, M.M.; DIJK, M.R.V. AND JANSE, C.J. (2005). Malaria Vaccines: Back to the Future?. SCIENCE, 307:528-530.

WEI, L.N. AND JOYS, T.M. (1985). Covalent Structure of Three Phase-1 Flagellar Filament Proteins of Salmonella. Journal Molecular Biology, 186, pp. 791-803. 
WEISS, W.R.; SEDEGAH, M.; BEAUDOIN, R.L.; MILLER, L.H. AND GOOD, M.F. (1988). CD8+ T cells (cytotoxic/supressors) are required for protection in mice immunized with malaria sporozoites. Proc. Natl Acad Sci USA, 85:573-576.

WEISS, W.R.; MELLOUK, S.; HOUGHTEN, R.; SEDEGAH, M.; KUMAR, S.; GOOD, M.F.; BERZOFSKY, J.A.; MILLER, L.H. AND HOFFMAN, S.L.(1990). Cytotoxic T cells recognize a peptide from the circunsporozoite protein on malaria-infected hepatocytes. J. Exp. Med., 171:763-773.

WHO-WORLD HEALTH ORGANIZATION (2002). The global malaria situation: current tools for prevention \& control. 55th. World Health Assembly. Global Fund to Fight AIDS, Tuberculosis \& Malaria, WHO document no. 55. Available at: http://www.who.int/gb/ebwha/pdf_files/WHA55/ea55id6.pdf.

ZHANG, G. AND GHOSH, S. (2001). Toll-like receptor-mediated NF- $\kappa B$ activation: a phylogenetically conserved paradigm in innate immunity. The Journal of Clinical Investigation, 107:13-19.

YONEKURA, K.; MAKI-YONELURA, S. AND NAMBA, K. (2003). Complete atomic model of the bacterial flagellar filament by electron cryomicroscopy. Nature, 424: 643-647. 